ORNL/TM-12784

\title{
Application of the TRUEX Process to Highly Irradiated Targets
}

MARTIN MARUETRA

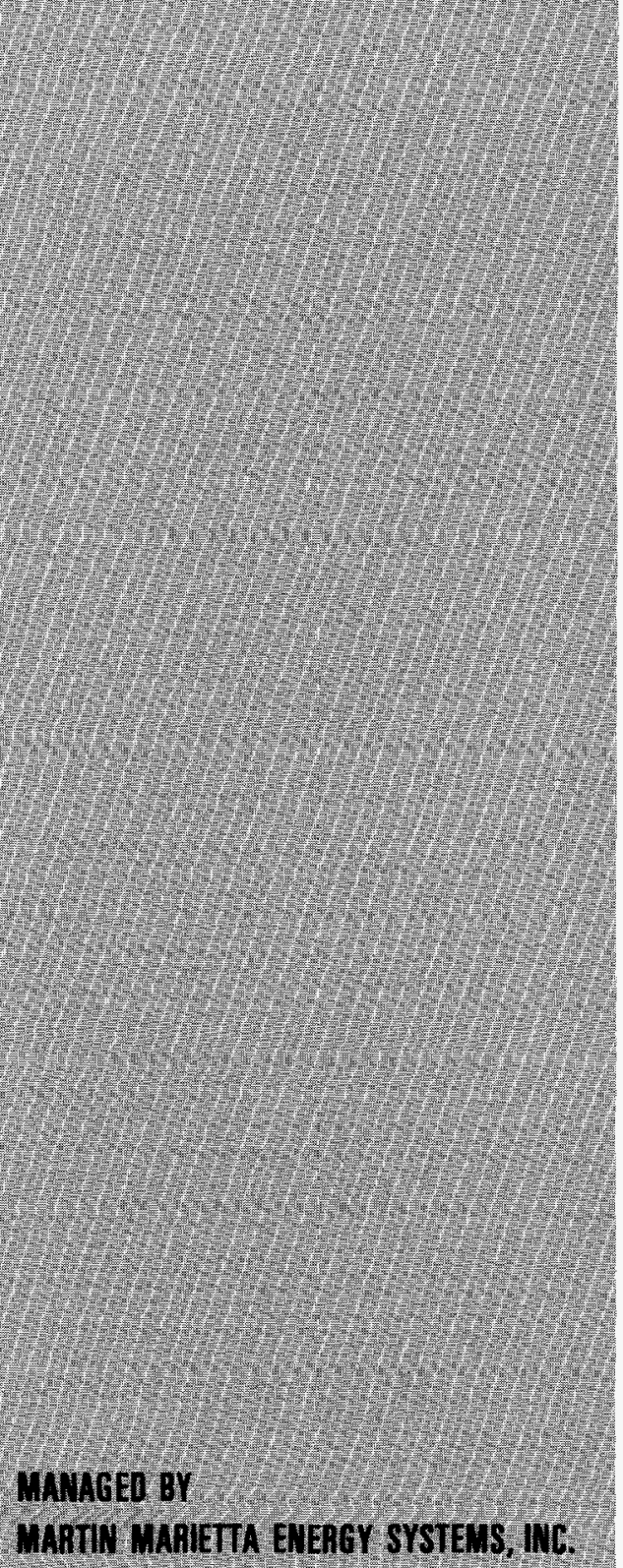

FOR THE UUITED STITES

DEPARTIEET OF ENEREY

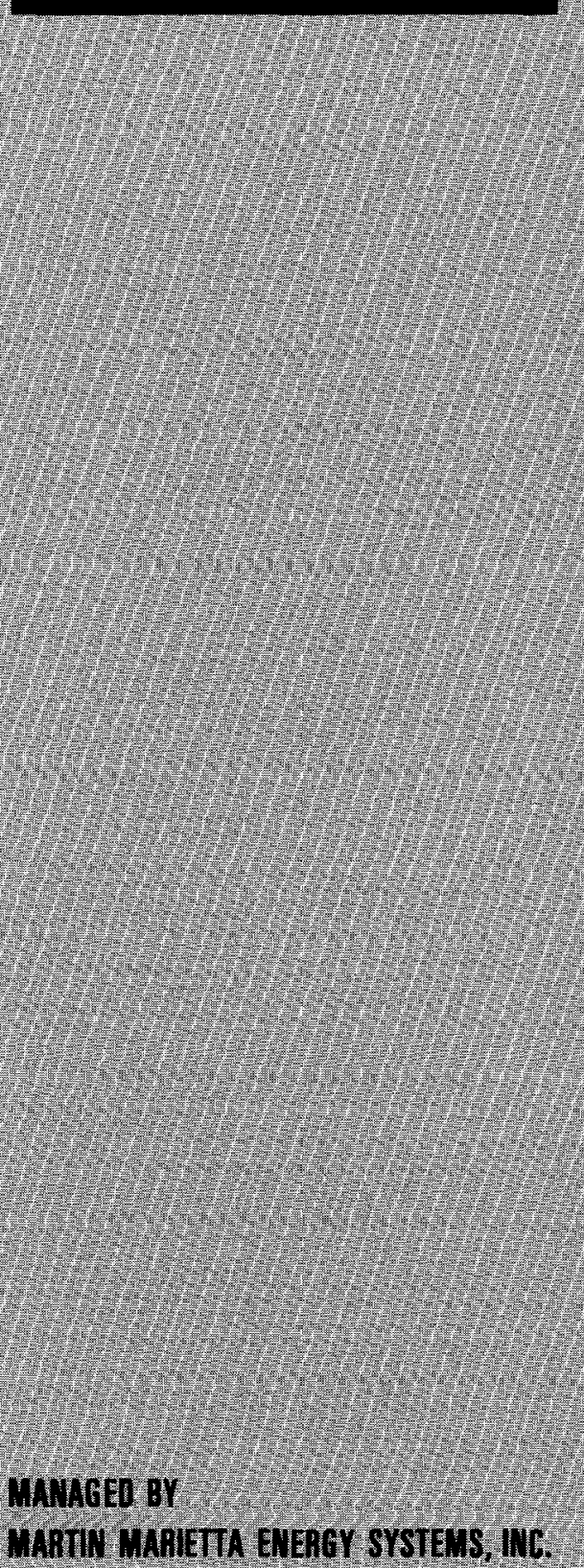

L. K. Felker

D. E. Benker

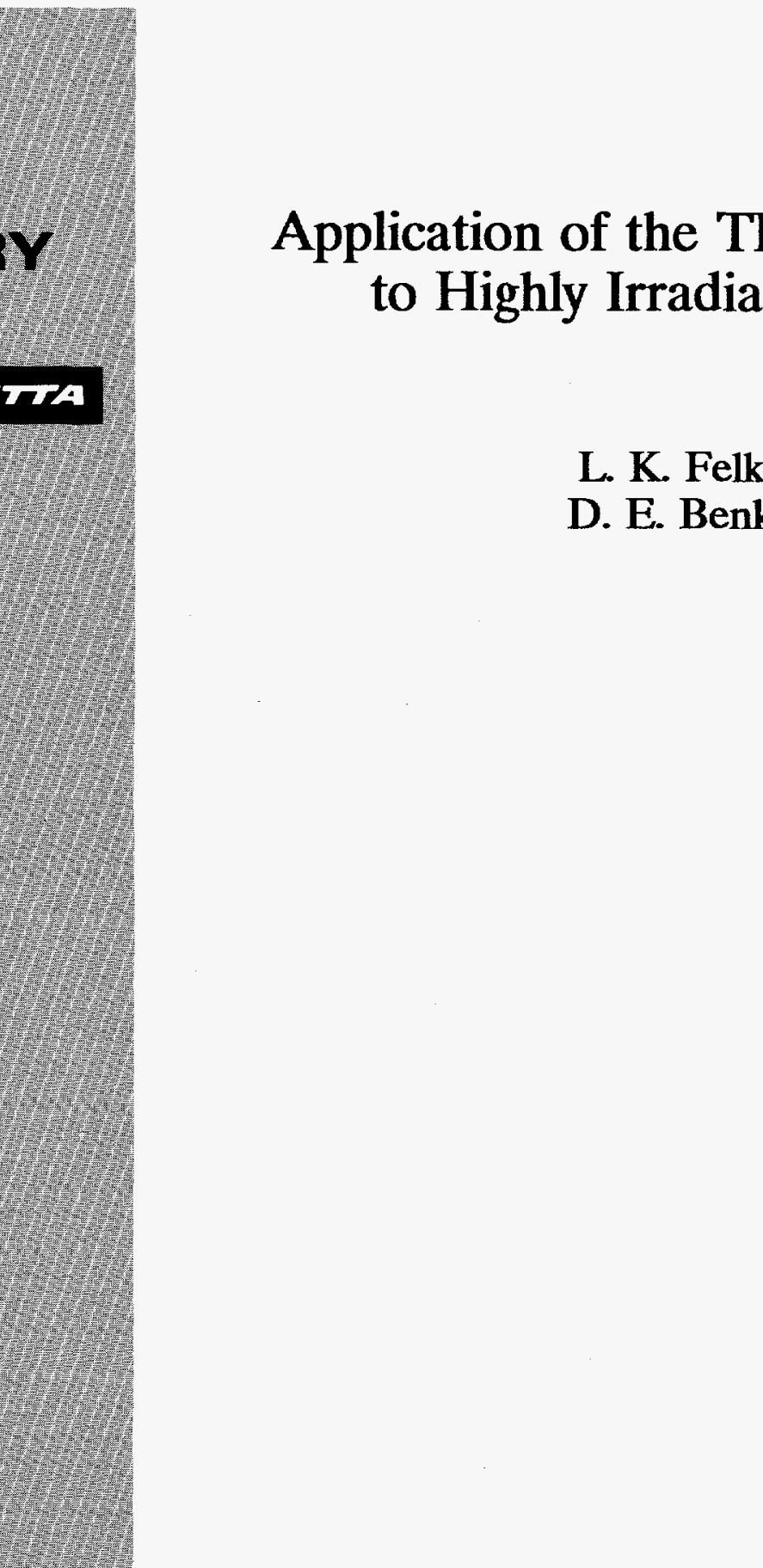

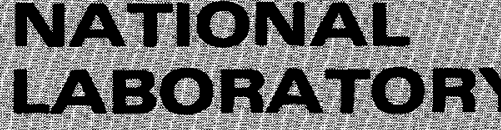

\section{(1)}

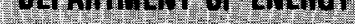


This report has been reproduced directly from the best available copy.

Available to DOE and DOE contractors from the Office of Scientific and Technical Information, P.O. Box 62, Oak Ridge, TN 37831; prices available from (615) 576-8401, FTS 626-8401.

Available to the public from the National Technical Information Service, U.S. Department of Commerce, 5285 Port Royal Rd., Springtield, VA 22161.

This report was prepared as an account of work sponsored by an agency of the United States Government. Neither the United States Government nor any agency thereof, nor any of their employees, makes any warranty, express or implied, or assumes any legal liability or responsibility for the accuracy, completeness, or usefulness of any information, apparatus, product, or process disclosed, or represents that its use would not infringe privately owned rights. Reference herein to any specitic commercial product, process, or service by trade name, trademark, manufacturer, or otherwise, does not necessarily constitute or imply its endorsement, recommendation, or favoring by the United States Government or any agency thereof. The views and opinions of authors expressed herein do not necessarily state or reflect those of the United States Government or any agency thereof. 


\section{DISCLAIMER}

Portions of this document may be illegible in electronic image products. Images are produced from the best available original document. 
ORNL/TM-12784

\author{
CHEMICAL TECHNOLOGY DIVISION
}

\title{
APPLICATION OF THE TRUEX PROCESS TO HIGHLY IRRADIATED TARGETS
}

\author{
L. K. Felker \\ D. E. Benker
}

March 1995

Prepared by the OAK RIDGE NATIONAL LABORATORY

Oak Ridge, Tennessee 37831 managed by

MARTIN MARIETTA ENERGY SYSTEMS, INC.

for the

U.S. DEPARTMENT OF ENERGY

under contract DE-AC05-84OR21400 
. 


\section{CONTENTS}

Page

FIGURES $\ldots \ldots \ldots \ldots \ldots \ldots \ldots \ldots \ldots \ldots \ldots \ldots \ldots \ldots \ldots \ldots \ldots \ldots \ldots \ldots \ldots$

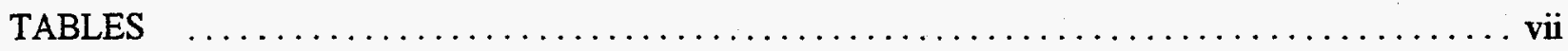

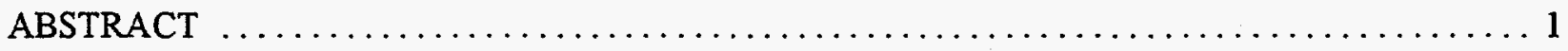

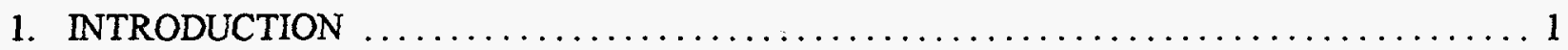

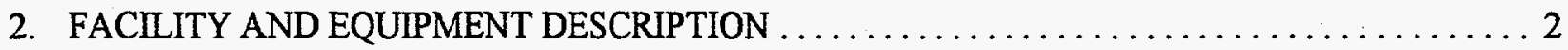

2.1 RADIOCHEMICAL ENGINEERING DEVELOPMENT CENTER $\ldots \ldots \ldots \ldots \ldots \ldots \ldots 2$

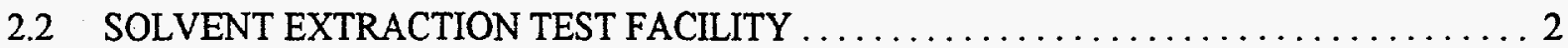

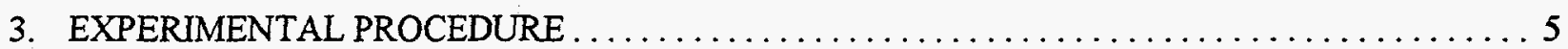

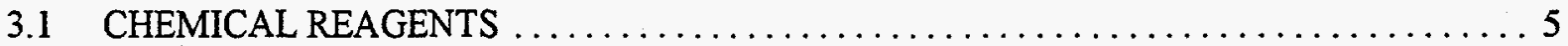

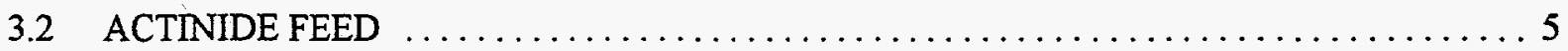

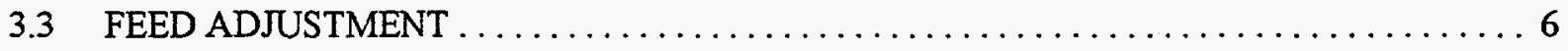

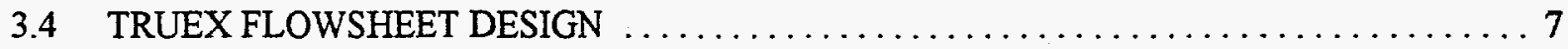

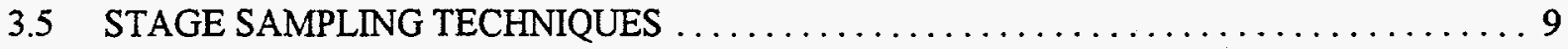

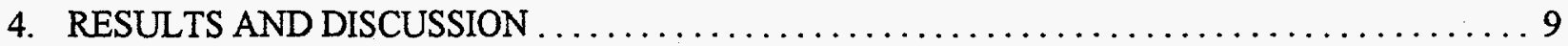

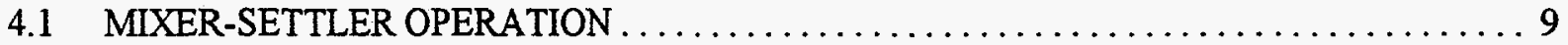

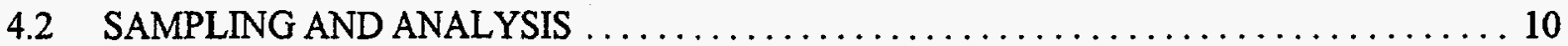

4.3 PRODUCT DISTRIBUTION AND DECONTAMINATION FACTORS $\ldots \ldots \ldots \ldots \ldots 11$

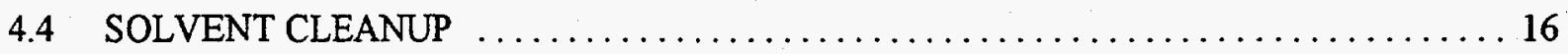

5. GENERIC TRUEX MODEL (GTM) COMPARISONS $\ldots \ldots \ldots \ldots \ldots \ldots \ldots \ldots \ldots \ldots \ldots \ldots$

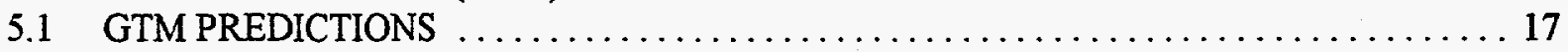

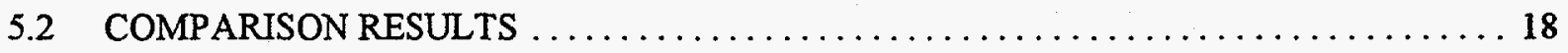

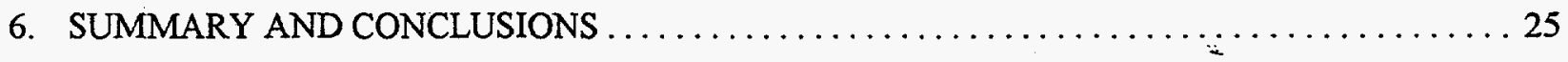

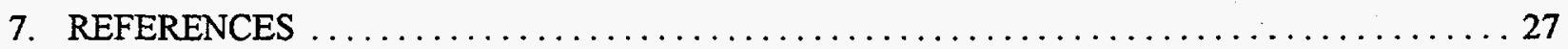

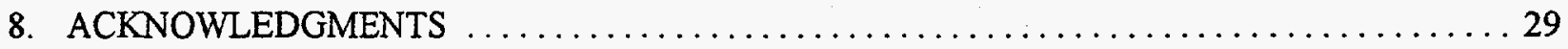

APPENDIX A: TABLES OF ANALYTICAL DATA FOR THE TRUEX TESTS $\ldots \ldots \ldots \ldots \ldots \ldots 1$ 
•

- 


\section{FIGURES}

Figure $\quad \underline{\text { Page }}$

1 Photograph of the SETF mixer-settler equipment rack $\ldots \ldots \ldots \ldots \ldots \ldots \ldots \ldots \ldots \ldots$

2 Schematic of the design flowsheet for the TRUEX tests $\ldots \ldots \ldots \ldots \ldots \ldots \ldots \ldots \ldots \ldots$

3 Plutonium concentration profile for the plutonium stripping section $\ldots \ldots \ldots \ldots \ldots \ldots \ldots$

4 Ruthenium concentration profile for the extraction scrubbing section $\ldots \ldots \ldots \ldots \ldots \ldots \ldots$

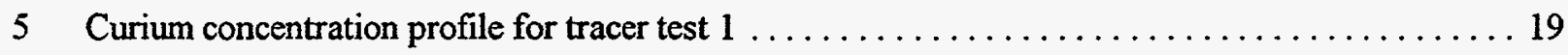

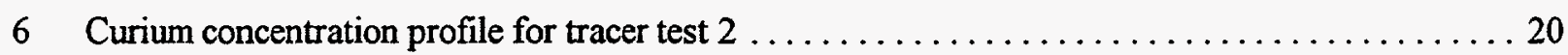

7 Curium concentration profile for the design test $\ldots \ldots \ldots \ldots \ldots \ldots \ldots \ldots \ldots \ldots \ldots \ldots \ldots$

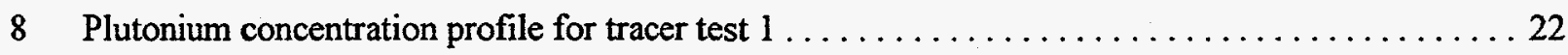

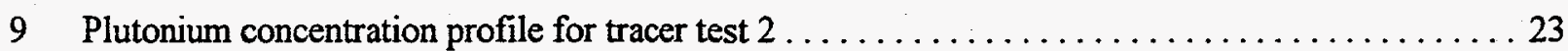

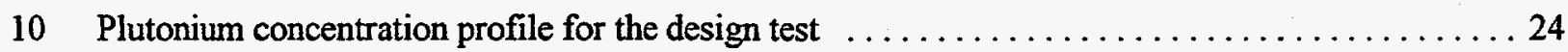


.

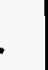




\section{TABLES}

Table

Page

1 Dissolution product concentration for TRUEX tests $\ldots \ldots \ldots \ldots \ldots \ldots \ldots \ldots \ldots \ldots$

2 Distribution of products in TRUEX tests $\ldots \ldots \ldots \ldots \ldots \ldots \ldots \ldots \ldots \ldots \ldots \ldots \ldots \ldots \ldots \ldots$

3 Decontamination factors for product streams $\ldots \ldots \ldots \ldots \ldots \ldots \ldots \ldots \ldots \ldots \ldots \ldots \ldots$

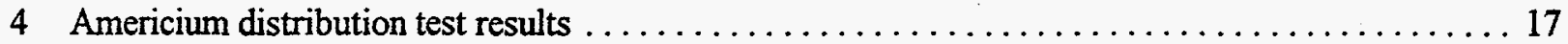

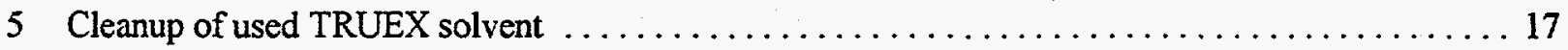




\title{
APPLICATION OF THE TRUEX PROCESS TO HIGHLY IRRADIATED TARGETS
}

\author{
L. K. Felker \\ D. E. Benker
}

\begin{abstract}
The Radiochemical Engineering Development Center (REDC) at Oak Ridge National Laboratory processes highly irradiated targets for the Mark 42 program to separate americium, curium, and plutonium. Argonne National Laboratory (ANL) has developed the TRUEX process for the removal of transuranic elements from aqueous waste streams and a computer model that aids in the design of potential flowsheets. Because the TRUEX process is attractive for application to the large volumes of high-activity tank wastes stored at various Department of Energy sites, a test of the process on the highly irradiated Mark 42 target material would yield useful information on the performance of the process under "real" conditions. Researchers at ANL used the Generic TRUEX Model (GTM) to design a TRUEX flowsheet to process Mark 42 target material. Researchers at the REDC refurbished the Solvent Extraction Test Facility mixer-settler contactors and conducted three test runs using the TRUEX process. The results from the three demonstration tests are presented along with the predicted results from the GTM.
\end{abstract}

\section{INTRODUCTION}

Large volumes of liquid radioactive wastes are stored in underground storage tanks at various sites throughout the Department of Energy (DOE) complex. These waste solutions have been stored for many years and have received increasing attention because of potential leakage or undesirable chemical reactions of the waste solutions. With a future goal of removing the waste solutions for processing and storage of the radioactive components in a more concentrated and stable form, various processes and processing techniques are being investigated to accomplish this task. The emphasis of these efforts has been focused at the Hanford, Washington, site; however, other sites may also benefit from these technology developments. Many of these waste solutions contain transuranic elements, which pose an additional disposal problem because of their long half-lives and high toxicity. Argonne National Laboratory (ANL) researchers have developed the TRUEX process for the removal of the transuranium elements from waste solutions. ${ }^{1}$ They have also developed a computer model, the Generic TRUEX Model (GTM), ${ }^{2}$ which can be used in the design of a processing flowsheet for a particular waste solution to predict the decontamination factors for the various components. Much of the development work with the GTM 
was done with tracer-level solutions and synthetic waste solutions in laboratory-scale experiments. The application of the TRUEX process on a larger scale with actual waste solutions has been limited.

The Radiochemical Engineering Development Center (REDC) at Oak Ridge National Laboratory (ORNL) has been processing irradiated Mark $42 \mathrm{PuO}_{2}$ targets since $1991 .^{3}$ These targets were highly irradiated (>87 at.\% fission) and contain curium, americium, plutonium, and the associated fission products. Within the REDC is the Solvent Extraction Test Facility (SETF), which was designed to test light-water reactor (LWR) and fast breeder reactor (FBR) fuel reprocessing. ${ }^{4}$ The SETF equipment is contained in a shielded hot cell; therefore, high levels of radioactivity can be used. Within the SETF are three banks of 16-stage mixer-settler contactors capable of handling kilogram quantities of irradiated fuels in nitric acid solutions. This equipment had been in standby for 5 to 6 years; therefore, reburbishment and adaptation of the mixer-settler contactors were necessary for any potential use. The desire was to use the SETF mixer-settlers to test the application of the TRUEX process to the Mark 42 irradiated targets. This would serve a twofold purpose, first, to test the feasibility of using the TRUEX process in Mark 42 target processing to make separate, purified plutonium and americium/curium product fractions, and secondly, to take a number of stream and profile samples for analysis to verify the GTM using gram quantities of americium-curium and dekagram quantities of plutonium.

\section{FACILITY AND EQUIPMENT DESCRIPTION}

\subsection{RADIOCHEMICAL ENGINEERING DEVELOPMENT CENTER}

The REDC at ORNL processes irradiated targets and assemblies for the DOE Energy Research Heavy Element Program and the DOE Defense Production Program to recover transuranium elements. Within the REDC is a multipurpose radiochemical facility at Building 7920 consisting of nine heavily shielded hot cells, where much of the chemical processing activities are performed. The building was designed for absolute containment of the highly radioactive materials. All operations and maintenance activities are performed using remotely operated manipulators. Smaller items of chemical processing equipment such as valves, pumps, and ion-exchange columns are mounted on modular racks inside the cells. This design allows flexibility to incorporate new processes or change existing processes for increased efficiency.

\subsection{SOLVENT EXTRACTION TEST FACILITY}

One of the shielded hot cells is dedicated to the SETF. This facility was designed to test LWR/FBR fuel reprocessing flowsheets. The central feature of the SETF equipment is a rack containing three banks of 16-stage 
mixer-settlers. A photo of the equipment rack containing the mixer-settler banks is shown in Fig. 1. This equipment was designed to process several kilograms of heavy-metal fuels per day. Each mixer-settler is fabricated of stainless steel with a quartz glass front window. All of the settling chambers are located on the front side and thus can be observed through the hot cell window. The stage volumes are $\sim 80 \mathrm{~mL}$ ( $30 \mathrm{~mL}$ for the mixing chamber and $50 \mathrm{~mL}$ for the settling chamber). The organic phase enters the right side of each mixersettler bank and flows to the left, whereas the aqueous phase enters the left side and flows to the right. The mixed phases enter the settling chamber through a middle port. The phase separate and the organic overflows into the adjacent mixing stage to the left, while the aqueous phase underflows through a weir plate into the mixing chamber of the adjacent stage to the right. The interface levels are regulated by a hydrostatic leg in the aqueous solution outlet line. Several associated tanks are located outside the hot cell and are available for the metering of scrub and strip solutions to the mixer-settler banks. There are also several in-cell tanks for holding the various processing solutions. The SETF had been operated from 1978 to 1986, when the final fuel reprocessing tests were concluded and the equipment was put in standby. In 1993, the mixer-settlers and associated equipment were refurbished and made operational for use in the TRUEX demonstration on Mark 42 irradiated targets.

Several modifications were necessary in the mixer-settler equipment for use in the TRUEX runs with the Mark 42 dissolution product solution. A malfunctioning electronic controller on the hot feed system was bypassed, and the hot feed was pumped from the feed tanks to the mixer-settler using a metering pump on a variable-speed motor. The use of recycled organic solvents had not been tested previously. In all the earlier tests with the mixer-settlers, the organic solvents were used on a once-through basis. Because of the cost and the desire to look at the radiation effects on the solvent, fresh solvent was used for the first test and recycled for use in all subsequent tests. To provide a constant, controllable flow of organic solvent to the mixer-settlers, two additional metering pumps were incorporated into the mixer-settler setup. These pumps were not capable of pulling the organic solvent from the larger holding tanks, so an intermediate tank was used to provide a feed tank for the pumps. The organic solvent was transferred in 4- to 5-L batches by vacuum from the larger holding tank to the intermediate tank and then pumped from the intermediate tank to the mixer-setters with the metering pumps. An organic feed was required to both the extraction bank and the americium-curium strip bank; therefore, a teed line was used between the feed tanks and the pumps. To get an accurate determination of the organic flow rates, the metering pumps were calibrated with the organic solvent before each run, and a calibration check was made after each run to ensure that the pumps remained in the proper range. Monitoring of the effluent catch tank volumes also gave a check of the flow rates during the runs. 


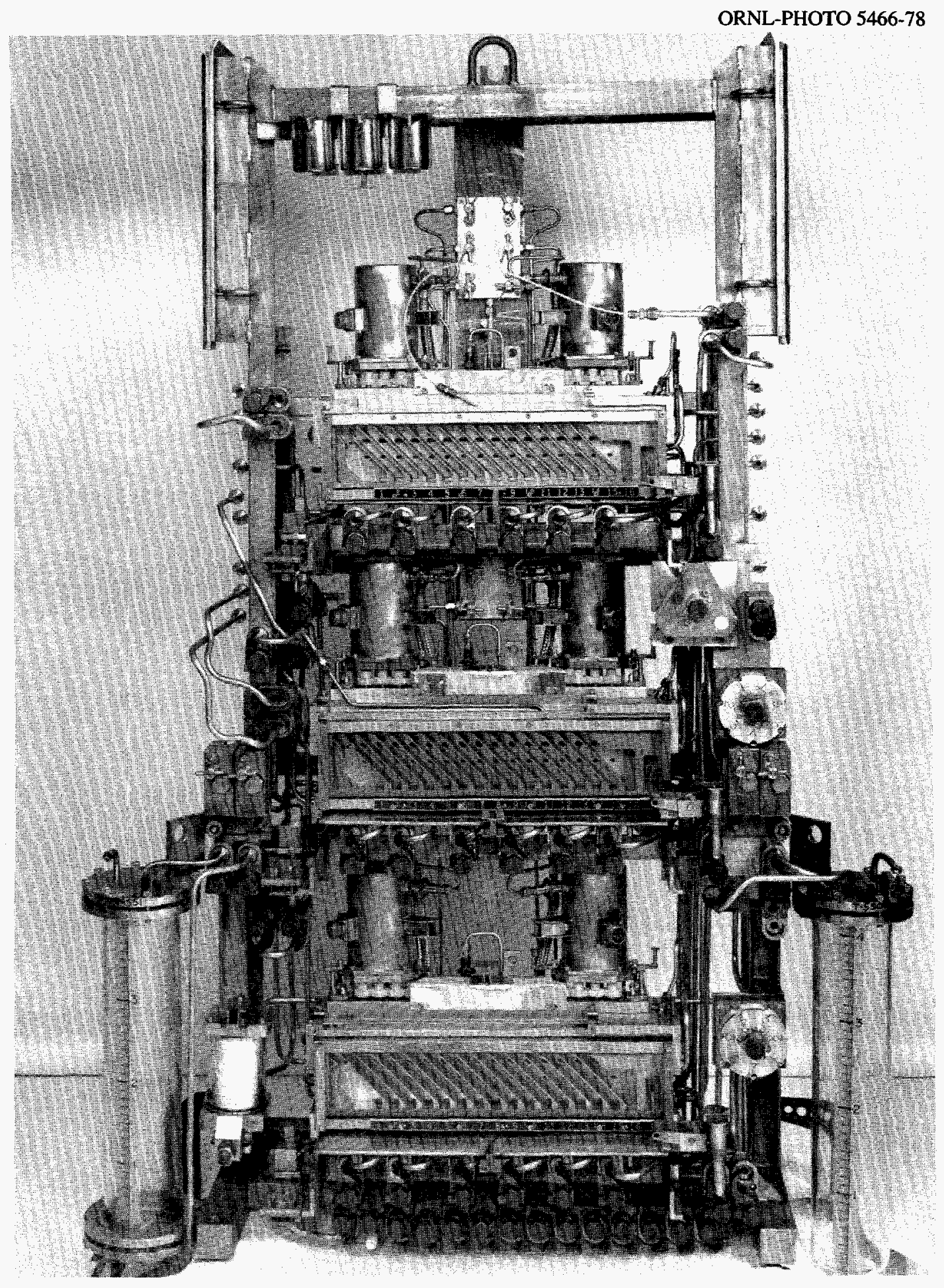

Fig. 1. Photograph of the SETF mixer-settler equipment rack. 


\section{EXPERIMENTAL PROCEDURE}

\subsection{CHEMICAL REAGENTS}

The octyl (phenyl)-N,N-diisobutylcarbamolymethylphosphine oxide (CMPO) used in the demonstration tests was obtained from ATOCHEM North America as solvent extraction grade ( $95-97 \%$ purity) reagent. The tributyl phosphate (TBP) used was obtained from Stauffer Chemical Company, and the $n$-paraffin hydrocarbon solvent (Norpar® 12) was obtained from Exxon Chemical Company. All other chemicals used were reagent grade, and the prepared solutions were analyzed for proper concentration. No further purification of the CMPO was performed because of the large quantity needed for the demonstration tests. The prepared TRUEX solvent was analyzed for purity and concentration using the americium distribution test procedure recommended by ANL and described in Sect. 4.4, Solvent Cleanup.

\subsection{ACTINIDE FEED}

The actinide feed for the TRUEX tests was prepared from the dissolution of selected segments from a Mark 42 irradiated target assembly. The Mark 42 assemblies are a plutonium dioxide-aluminum cermet extrusion with an aluminum cladding. The dissolution of the selected segment pieces was accomplished using a two-step process: caustic dissolution to remove the aluminum followed by acid dissolution to dissolve the actinides and most of the fission products. This two-step process coupled with filtration produced a solids-free acid product solution suitable as feed material for the TRUEX mixer-settler tests. The caustic dissolution was accomplished by submerging the segment pieces in $2.25 \mathrm{MNaNO}_{3}$, heating to $92 \pm 2^{\circ} \mathrm{C}$, and metering in $10 \mathrm{M}$ $\mathrm{NaOH}$ at a controlled rate to sustain the dissolution reaction. The caustic solution containing the bulk of the aluminum and caustic soluble fission products (i.e., cesium) was then filtered through a sintered stainless steel filter element and discarded as waste. The filter was then backflushed with concentrated nitric acid and water to yield an 8.0 M $\mathrm{HNO}_{3}$ solution in the dissolver tank, where the actinides and the remaining fission products were quantitatively dissolved to yield an acid dissolution product. The acid dissolution product was initially filtered through a 10- $\mu \mathrm{m}$ graded-density polypropylene filter to remove any solids (primarily undissolved silica activation products). Table 1 gives the dissolution product concentrations for the feed to the mixer-settler tests. The fission product mass concentrations are based on calculated values from the ORIGEN computer model, which predicts the concentrations of species in irradiated materials. 
Table 1. Dissolution product concentrations for TRUEX tests ${ }^{a}$

\begin{tabular}{|c|c|c|c|}
\hline Actinides, $g / L$ & & Radioactivities, $\mathrm{Ci} / \mathrm{L}$ & \\
\hline Curium & 0.51 & ${ }^{244} \mathrm{Cm}$ & 39.0 \\
\hline Americium & 1.3 & ${ }^{241,243} \mathrm{Am}$ & 0.53 \\
\hline Plutonium & 3.0 & Plutonium & 10.6 \\
\hline \multicolumn{4}{|c|}{ Fission products, $\mathrm{g} / \mathrm{L}$} \\
\hline Zirconium $^{b}$ & 2.8 & ${ }^{134} \mathrm{Cs}$ & 0.13 \\
\hline Molybdenum $^{b}$ & 3.7 & ${ }^{137} \mathrm{Cs}$. & 1.0 \\
\hline Ruthenium $^{b}$ & 4.1 & ${ }^{106} \mathrm{Ru}$ & 0.95 \\
\hline Palladium $^{b}$ & 4.3 & ${ }^{154} \mathrm{Eu}$ & 2.6 \\
\hline Rare earths $s^{b}$ & 11.0 & ${ }^{155} \mathrm{Eu}$ & 1.2 \\
\hline
\end{tabular}

\subsection{FEED ADJUSTMENT}

Two feed adjustments were made on the feed solution for the TRUEX demonstration tests. The first was the preparation of the feed solution for the two tracer-level tests that were performed. The acid dissolution product was heated to $60-70^{\circ} \mathrm{C}$ and sparged with nitric oxide to adjust the plutonium to the $\mathrm{Pu}(\mathrm{IV})$ valence state. The valence adjustment was deemed complete when two successive samples showed $>95 \% \mathrm{Pu}$ (IV) content. The $\mathrm{Pu}$ (IV) content was determined using a thenoyltrifluoroacetone (TTA) extraction method that omitted any plutonium valence adjustment steps. A small portion of this solution (about 5\%) was transferred to the feed tank for the mixer-settlers and diluted with $1.0 \mathrm{MHNO}_{3}$ to yield a dilute actinide solution for the two tracer-level tests. For the final design test, a second feed adjustment was necessary to yield a feed solution at the proper acid and actinide concentrations. The remaining dissolution solution was evaporated to $2.0 \mathrm{~L}$ to remove excess acid and diluted with $0.1 \mathrm{~N} \mathrm{HNO}_{3}$ to $8.0 \mathrm{~L}$ to give a solution near the proper acid concentration for the design TRUEX test. Again, the plutonium valence was adjusted by heating the solution to $60-70^{\circ} \mathrm{C}$ and sparging with nitric oxide until two successive samples showed $>95 \% \mathrm{Pu}$ (IV) content. This solution was diluted to $15 \mathrm{~L}$ to give the final acid concentration of $1.0 \mathrm{M}$. The feed solutions for all three tests were filtered through both a $1-\mu \mathrm{m}$ gradeddensity polypropylene filtered and a deep-bed filter of Celite and SuperCel silica-based filter aid to yield a solidsfree feed solution for the mixer-settler operation. 


\subsection{TRUEX FLOWSHEET DESIGN}

ANL personnel provided the flowsheet design for the TRUEX test based on the predictions from the GTM. A schematic diagram of the proposed flowsheet is shown in Fig. 2. A letter report ${ }^{5}$ was issued by ANL personnel which described the criteria for the flowsheet design and the proposed operation in the ORNL SETF mixersettlers. The flowsheet design was based on the dissolution of one segment or one-eighth of a Mark 42 assembly. The initial caustic dissolution would eliminate most of the aluminum matrix of the target as well as most of the cesium, silica, and radioactive gases. The caustic dissolution should also eliminate some of the strontium and zinc. The acid dissolution product would then contain the actinides, rare earths, and other acid-soluble fission products. The initial criteria for the flowsheet design was to produce an americium, curium, and rare earth product containing $<0.1 \%$ of the plutonium and a plutonium product that contains $<1 \%$ of the americium, curium, and rare earths. By adding oxalate to the extraction section of the TRUEX flowsheet, the plutonium, americium, curium, and the rare earths should extract; and the $\mathrm{Zr}, \mathrm{Mo}, \mathrm{Rh}, \mathrm{Ru}$, and other fission products should be complexed and remain in the aqueous raffinate.

Normally, oxalate is added to the feed solution well before the feed is transferred to the contactors. This ensures that there is adequate time to form the necessary complexes with zirconium and molybdenum. However, because the concentrations of the americium, curium, and rare earths were relatively high in this feed solution, the addition of oxalate to the feed solution could cause precipitation of the actinides as oxalates. To help prevent this precipitation, the oxalate was instead added to the first scrub stage, which will have lower actinide and rare earth concentrations. This, too, was a concern, in that this may not give sufficient time for the oxalate to complex the noble metals before they are extracted, or, because of the high concentrations, the rare earths might precipitate before they are extracted and cause plugging problems in the mixer-settler banks. The extraction-scrubbing stages of the mixer-settlers were tested with neodymium as the feed to determine if precipitation problems would occur. Only a slight precipitate was noted in the test run in the stage where the oxalate was added; so no problems were foreseen in the in-cell TRUEX tests.

In the flowsheet designed by ANL, the first contactor was used to coextract the americium, curium, and plutonium from the aqueous feed and leave $<100 \mathrm{nCi} / \mathrm{mL}$ alpha activity in the raffinate. Three scrub solution sections were used in the flowsheet design. The first was the addition of oxalic acid to minimize the extraction of $\mathrm{Zr}, \mathrm{Ru}, \mathrm{Rh}$, and $\mathrm{Mo}$ into the solvent. The second scrub section introduces the aluminum that keeps the oxalic acid out of the strip section where the low acid would allow rare earth, americium, and curium oxalate precipitates to form. If the oxalic acid were present in the strip section at high enough concentrations, the desired separation would be compromised. The third scrub consisted of dilute $\mathrm{HNO}_{3}$ to keep aluminum and excess $\mathrm{HNO}_{3}$ out of 
ORNL DWG 93A-802

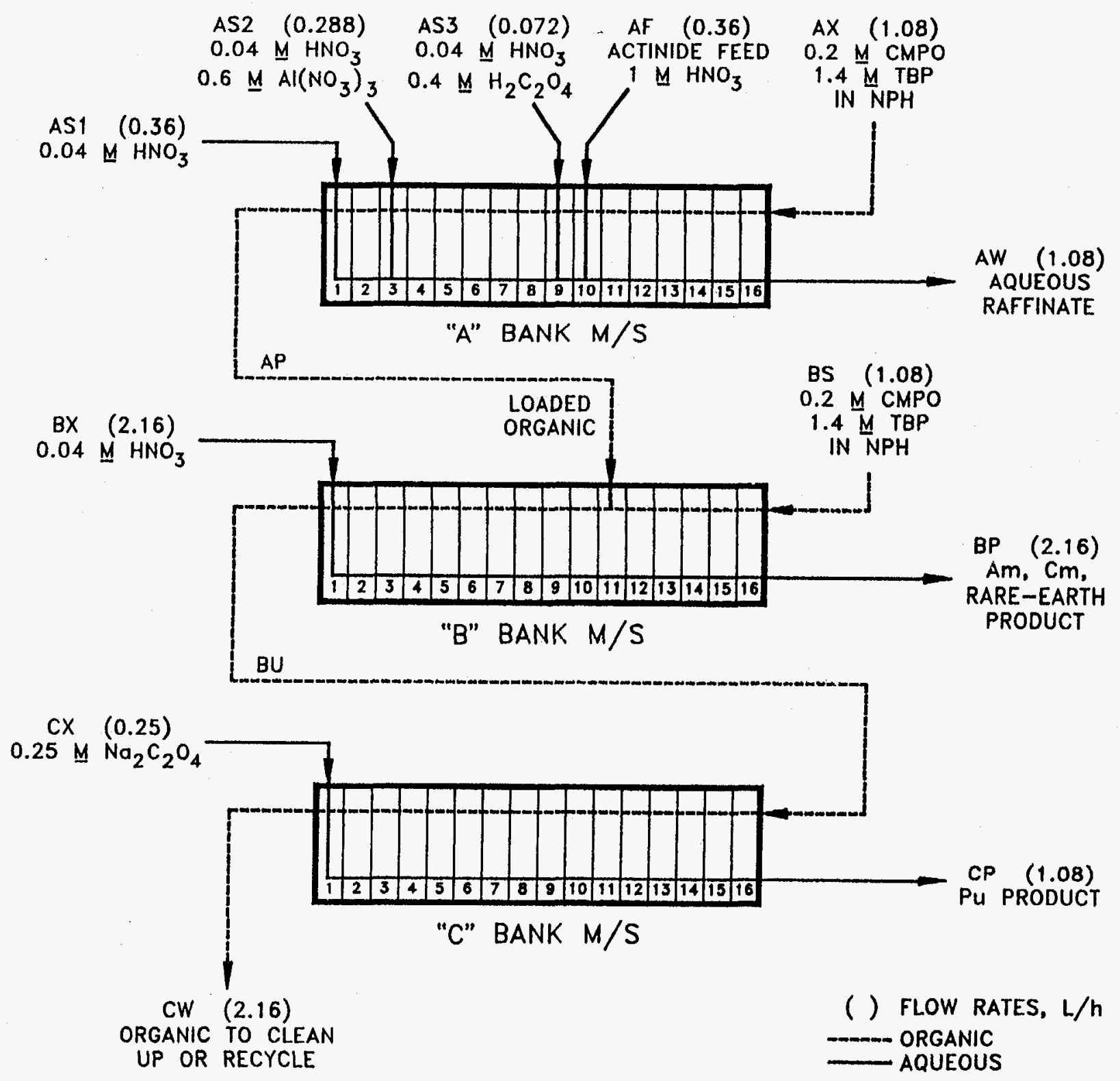

Fig. 2. Schematic of the design flowsheet for the TRUEX tests. 
the strip section. The second contactor was used to produce a purified, aqueous americium-curium product. Dilute nitric acid was used as the aqueous strip, and a scrub of fresh solvent was added to minimize the plutonium in the americium-curium product. The third contactor was to strip plutonium from the solvent using an aqueous strip of sodium oxalate.

The design flowsheet was used for the first tracer-level test. Some modifications were made for the second tracer-level test. The oxalic acid concentration was lowered from $0.4 M$ to $0.17 M$ in the A-Bank scrub section (Stream AS3) to better match the oxalate concentration with the actinide concentrations in the diluted feed. The plutonium strip solution was also changed from sodium oxalate to a dilute acid and hydroxylamine nitrate (HAN) solution ( $\left.0.01 \mathrm{MHNO}_{3}-0.05 \mathrm{MHAN}\right)$ to test the effectiveness of $\mathrm{HAN}$ solutions on plutonium stripping from the TRUEX solvent. For the final demonstration test, the original flowsheet design was used except for reducing the plutonium strip bank flow rate from 1.08 to $0.25 \mathrm{~L} / \mathrm{h}$. It was estimated from the tracer run data that the lower flow rate would be sufficient to strip the plutonium from the TRUEX solvent.

\subsection{STAGE SAMPLING TECHNIQUES}

The method used for sampling the various stages and phases during the TRUEX demonstration tests was used previously in the original SETF runs. The desire was to sample individual stages and specific phases in each stage with as little upset in steady-state conditions as possible. To accomplish this, blood-sampling needles were fitted into a 1 -in. by $1 / 8$-in.-thick fiberboard square, and the short needle was bent at a $90^{\circ}$ angle. A 6 -in. by 1/16th-in. ID Teflon heat-shrink tube was attached to the bent needle. These needle assemblies were put into the cell bank, and operating personnel using manipulators would insert the tube end of the needle assembly in the desired stage and phase for sampling. A preevacuated sample bottle with a diaphragm cap was inserted on the long needle of the assembly, and the solution (usually about $10-15 \mathrm{~mL}$ ) was pulled in the sample bottle. A new tube assembly was used for each sample to prevent cross contamination.

\section{RESULTS AND DISCUSSION}

\subsection{MIXER-SETTLER OPERATION}

For each of the three TRUEX test runs, the aqueous solutions were started first and the flow rates were adjusted to the proper range. When all of the aqueous flows were established, the organic solvent flows were started and the mixer-settler stages filled. After all of the stages were filled and steady-state flow rates were obtained, "hot" feed was introduced to the mixer-settler banks. In the first tracer-level test, the 
extraction-scrubbing section of the mixer-settler banks operated with no notable problems. The americiumcurium stripping sections contained small emulsion bands at the interface in each of the settling stages; however, these bands remained small enough that no overflow or underflow of the emulsion occurred. In the plutonium stripping section, two problems were identified. The first 13 stages of the plutonium strip section were operating in an aqueous continuous mode rather than an organic continuous mode. The final three stages did operate in the organic continuous mode but had a large emulsion band in each of the stages. Solids were also present in the plutonium stripping stages, but they did not appear to interfere with the mixer-settler operation. An analysis of the precipitate collected from the plutonium stripping stage did not show any major radioactivity; thus, it likely resulted from the sodium oxalate removing a scale from the lines in the system.

In the second tracer-level test, with the lower oxalic acid concentration in the extraction-scrubbing section and the change in the plutonium strip solution, the operation of the mixer-settlers was more stable. The emulsion bands in the americium-curium strip section were still present in the second test, but, again, no problems were attributed to these bands. The plutonium stripping section operated in the organic continuous mode, and no solids were present in this section.

In the third design test with the full activity feed solution, the operation of the mixer-settlers was less stable in the americium-curium strip section than in the first and second tests. In the extraction-scrubbing section of the mixer-settlers, a precipitate formed late in the run and appeared to plate out on the glass surface of the settling chamber. This precipitate did not appear to interfere with the mixer-settler operation (i.e., plugging the flow paths). In this test, hydraulic problems in the americium-curium strip-scrub section were encountered. The aqueous levels in the americium-curium stripping section increased to the point that the organic flow across this section could not be maintained, and flooding of the stages with aqueous was possible. To alleviate this problem, the aqueous flow rate in the americium-curium strip section was reduced from the nominal $2.08 \mathrm{~L} / \mathrm{h}$ to $1.25 \mathrm{~L} / \mathrm{h}$. This change in flow rate with minor adjustments in the stirrer speeds brought the section back into proper operation. As with both of the tracer-level tests, some emulsion bands were present in the americium-curium stripping section; however, no interference with the flows or sampling was noted. The plutonium stripping section in the design test operated well, with no precipitates formed or emulsion problems.

\subsection{SAMPLING AND ANALYSIS}

For each of the three tests, stage samples (exit streams from the three mixer-settler banks), profile samples (samples of selected stages across the mixer-settler bank), and end-of-run tank samples were taken. The type of sample (aqueous or organic) and the position (extraction, scrubbing, or stripping section) were considered in determining the analyses to be performed. Selected samples were analyzed for acid content, especially in the 
extraction-scrubbing section, to determine if the proper acid range was being maintained. All the samples were analyzed for gross alpha count and alpha pulse determination to give a quantitative result on the curium concentration as well as information on the plutonium concentrations in samples where the curium was removed. Selected aqueous samples were analyzed for total plutonium alpha counting and plutonium alpha pulse determination using a TTA extraction method. Analysis of samples using gamma spectrometry techniques yielded results on the concentration of the various fission products in the mixer-settler operation. The results of the various analytical determinations are given in the tables in Appendix A.

\subsection{PRODUCT DISTRIBUTION AND DECONTAMINATION FACTORS}

One of the design criteria for the TRUEX flowsheet was that the americium-curium product should contain $<0.1 \%$ of the plutonium and that a plutonium product should contain $<1 \%$ of the americium-curium. Table 2 shows the distribution of the curium, plutonium, and ruthenium in the aqueous raffinate, americium-curium product, plutonium product, and the waste organic. As seen in the table, the curium was well behaved in all three TRUEX tests. Greater than $99.99 \%$ of the curium was recovered in the americium-curium product in each of the tests, with slight losses to the aqueous raffinate, plutonium product, and waste organic.

The plutonium, however, was not as well behaved. In the two tracer-level tests, $>10 \%$ of the plutonium was stripped out with the americium-curium product. This is believed to be the result of a large excess of oxalic acid

Table 2. Distribution of products in TRUEX tests

\begin{tabular}{cllll}
\hline & $\begin{array}{l}\text { Aqueous } \\
\text { raffinate (\%) }\end{array}$ & $\begin{array}{l}\text { Americium-curium } \\
\text { product (\%) }\end{array}$ & $\begin{array}{l}\text { Plutonium } \\
\text { product (\%) }\end{array}$ & $\begin{array}{l}\text { Waste } \\
\text { organic (\%) }\end{array}$ \\
\hline Curium & & & & \\
TX-1 & 0.001 & 99.997 & 0.002 & 5. E-4 \\
TX-2 & 0.013 & 99.990 & $1 . E-4$ & 0.001 \\
TX-3 & 0.001 & 99.990 & 0.008 & 3. E-4 \\
& & & & \\
Plutonium & & 13 & 79 & 7.7 \\
TX-1 & 0.07 & 10 & 88 & 1.6 \\
TX-2 & 0.01 & 0.011 & 79 & \\
TX-3 & 0.003 & & & 16 \\
& & 10 & 12 & 30 \\
Ruthenium & & 4.4 & 5.4 & 30 \\
TX-1 & 62 & $<.6$ & 9.6 & \\
TX-2 & 60 & & & \\
TX-3 & 58 & & & \\
\hline
\end{tabular}


added in the extraction-scrubbing section because of the reduced feed concentration. The concentrations for the first tracer-level test were the concentrations recommended for the design test. For the second tracer-level test, the oxalic acid concentration was lowered, but the results may still indicate that there was an excess of oxalic acid.

In the design test, the oxalic acid was returned to the original design concentration, and the plutonium concentration in the americium-curium product was less than the design criteria. This reduced concentration of plutonium in the americium-curium product could have resulted from either a better match of oxalic acid and feed solution concentrations, or the reduced flow rate in the americium-curium strip section. In the design test, a larger percent of the plutonium reported to the waste organic, which was disturbing. The effectiveness of the plutonium stripping raises a concern for use of the TRUEX process for Mark 42 segment processing. This solution does, however, probably contain a much higher concentration of plutonium than the typical waste tank solution; and the extraction-stripping of plutonium in the waste tank solutions may be inconsequential.

The distribution of ruthenium is also shown in this table. The ruthenium appears to carry throughout the process, with a significant amount reporting to both products and the waste organic streams. This could be because of relatively slow ruthenium exchange kinetics with the oxalic acid addition to the feed solution. This would place more emphasis on the cleanup of the solvent before it is recycled and the secondary cleanup of the two products. An extensive solvent cleanup scheme was not employed with these demonstration tests; however, the treatment of PUREX solvents with activated alumina has been demonstrated to be very effective at removing ruthenium fission products ${ }^{6}$ and may be equally effective on the TRUEX solvent. Other methods or more effective methods of solvent cleanup have been and are being investigated to answer questions regarding the recycle of the TRUEX solvent. ${ }^{\text {? }}$

Another method for evaluating the effectiveness of a separations process is the calculation of decontamination factors (DFs) for the product streams. These DFs were calculated based on the median value of the exit stream stages from the two stage samples and the profile samples. These DFs are given in Table 3 for the two product streams for $\mathrm{Ru}, \mathrm{Sb}, \mathrm{Cs}, \mathrm{Eu}, \mathrm{Pu}$, and $\mathrm{Cm}$.

The DFs for ruthenium were not significantly high for either of the product streams. There appears to be a slight improvement in the design test, which might indicate an effect from the oxalic acid concentration on the removal of ruthenium in the aqueous raffinate. In all three tests, cesium did not extract and exited the process in the aqueous raffinate; however, higher DFs $\left(10^{5}\right)$ for cesium were expected. The europium DFs were as expected. No separation of the trivalent actinides and the trivalent rare earth fission products was expected-thus the DFs of 1 . The rare earths would follow the americium-curium, and thus the DFs for the plutonium product are similar to those of curium. The plutonium DFs may show the effect of the oxalic acid concentration or the change in the $\mathrm{O} / \mathrm{A}$ (organic/aqueous) ratio on the plutonium stripping behavior. The higher value in the design 
test may reflect the closer match of the oxalic acid concentration to the actinide and fission product concentrations or may result from the change in the design flow rate for the americium-curium strip solution. Good curium DFs were obtained for the plutonium product, as expected. The curium extracted well and was stripped effectively as an americium-curium product. The curium was used to measure the effectiveness of the extraction and stripping because the analysis of the samples for curium gives much better data with fewer interferences.

Table 3. Decontamination factors for product streams

$\begin{array}{llllll}\mathrm{Ru} & \mathrm{Sb} & \mathrm{Cs} & \mathrm{Eu} & \mathrm{Pu} & \mathrm{Cm}\end{array}$

Americium-curium product

$\begin{array}{rrrrrr}\text { TX-1 } & 13 & >16 & >100 & 1.1 & 12 \\ \text { TX-2 } & 24 & >38 & >300 & 1.0 & 7 \\ \text { TX-3 } & >49 & >5 & >400 & 1.2 & 1 \mathrm{E} 4\end{array}$

Plutonium product

TX-1

TX-2

The americium-curium extraction and stripping concentration profiles are shown in Sect. 5 with the GTM model comparisons. Figure 3 shows the concentration profiles across the plutonium stripping bank for the aqueous and organic phases for each of the three runs. The crossover of the aqueous and organic concentration profiles is an indication that there is an unstrippable plutonium species in the organic phase. Later tests with a PUREX flowsheet yielded good plutonium stripping behavior with low concentrations remaining in the organic phase. Because $\mathrm{Pu}(\mathrm{IV})$ is stripped from the TRUEX solvent at high $\mathrm{pH}(>10)$, acidic degradation products are much more powerful in stripping Pu(III) from the PUREX solvent at low $\mathrm{pH}$. Another area of interest was the behavior of the fission products in the flowsheet. Figure 4 gives the profile of ruthenium in the extractionscrubbing section of the flowsheet. It was hoped that most of the ruthenium would be complexed with the oxalic 


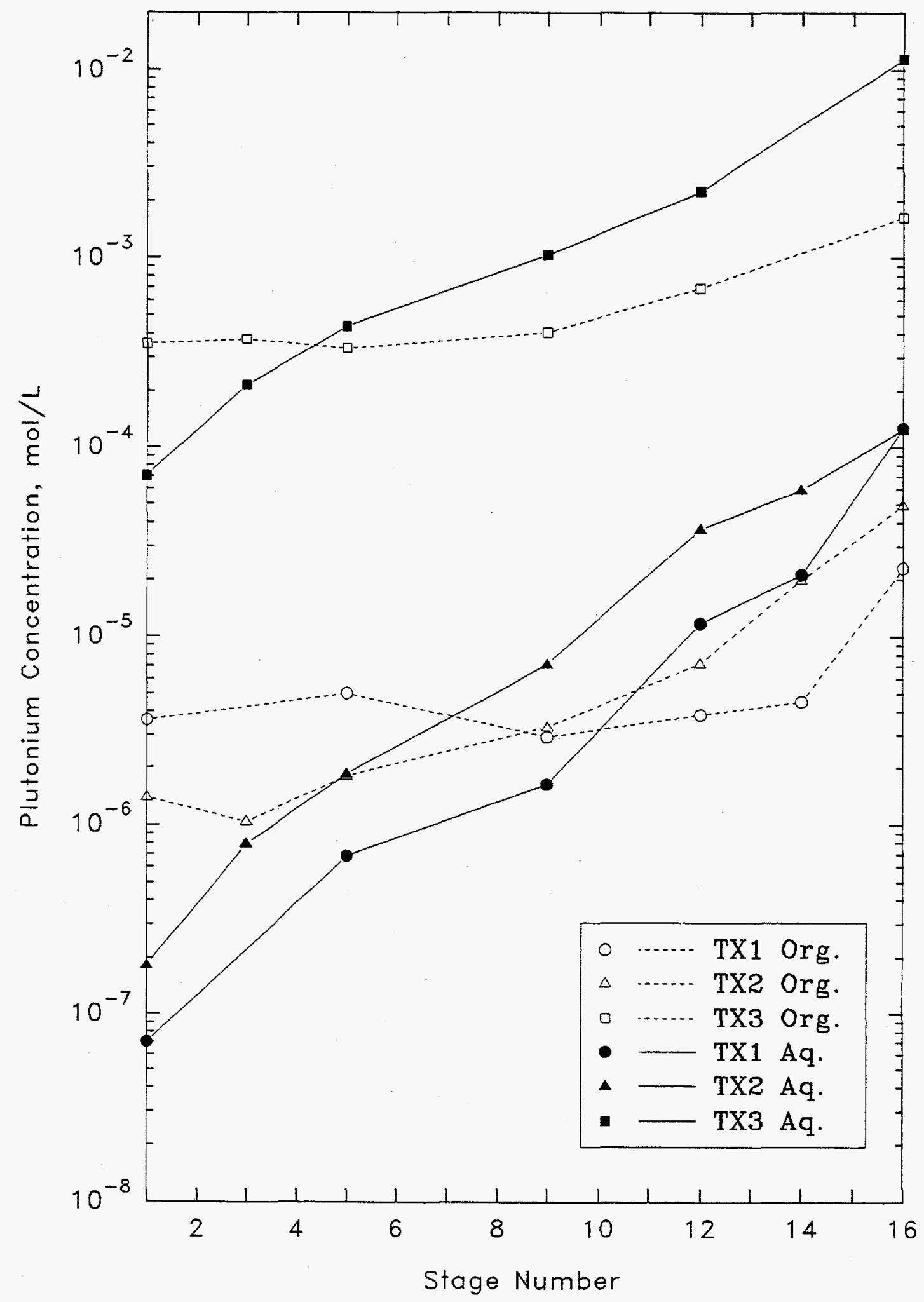

Fig. 3. Plutonium concentration profile for the plutonium stripping section. 


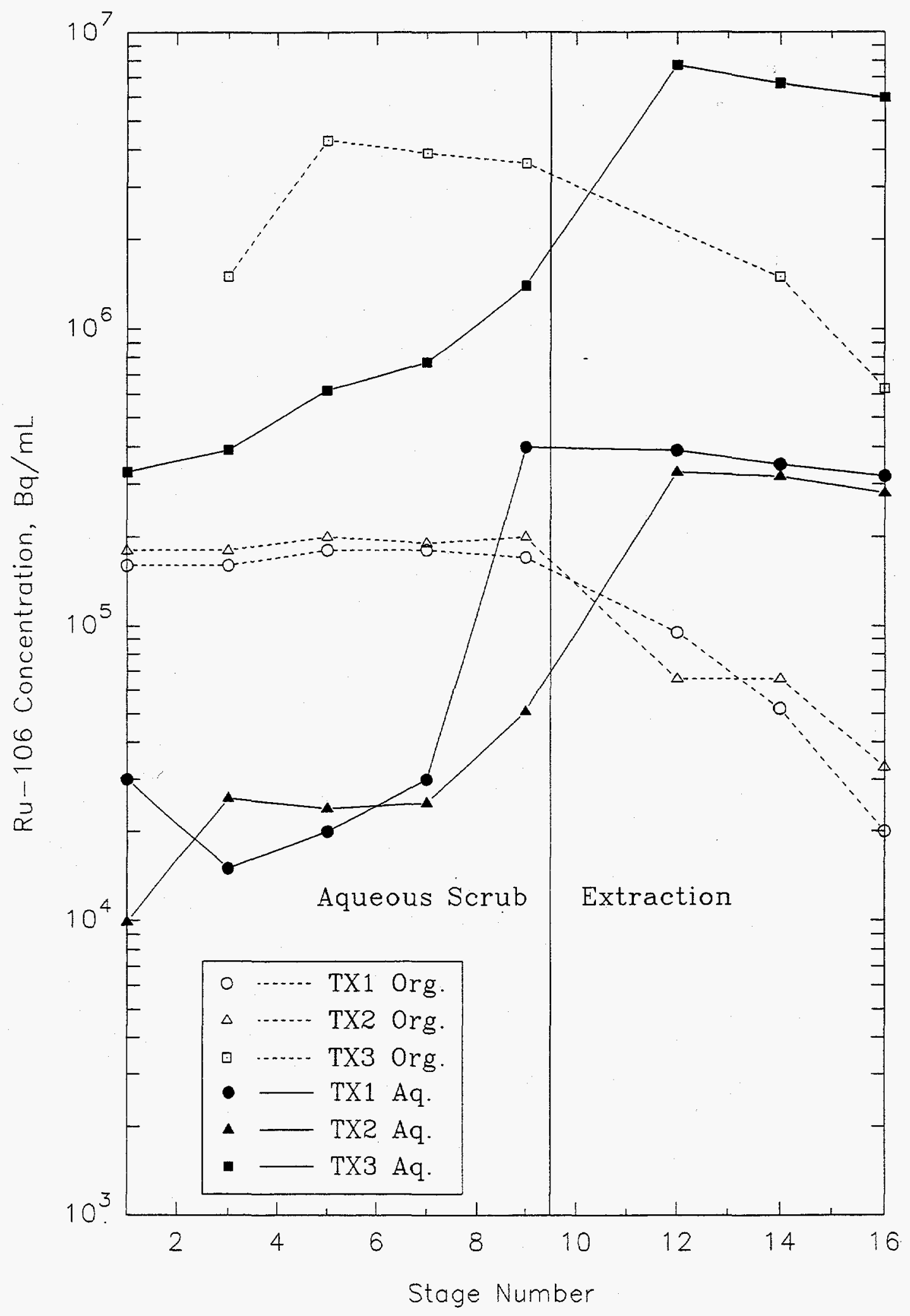

Fig. 4. Ruthenium concentration profile for the extraction scrubbing section. 
acid addition and be disposed of in the aqueous raffinate; however, measurable concentrations were carried over into the americium-curium stripping section and on into the waste organic, as seen in the product distribution results.

\subsection{SOLVENT CLEANUP}

A simplified solvent cleanup scheme was employed for the cleanup of the TRUEX solvent initially and between the demonstration tests. A 35-L batch of TRUEX solvent (1.4 $M$ TBP-0.2 $M$ CMPO in NPH) was prepared for use in all the TRUEX tests. The solvent was analyzed using the americium distribution procedure recommended by $\mathrm{ANL}$, which consisted of an americium distribution test at $0.01 M \mathrm{HNO}_{3}, 0.05 M \mathrm{HNO}_{3}$, and $2.0 \mathrm{MHNO}_{3}$. Acceptable values according to the procedure would fall in the range $0.02 \pm 0.01,0.23 \pm 0.02$, and $28 \pm 3$ for each of the three acid concentrations respectively. The distribution test at $0.01 M \mathrm{HNO}_{3}$ gives a sensitive measure of the acid impurities in the CMPO. The value at $0.05 \mathrm{MHNO}_{3}$ also gives a measure of the acid impurities and is important because this is an acid level used in the process. The final distribution test at 2.0 $\mathrm{M} \mathrm{HNO}_{3}$ gives a measure of the concentration of CMPO in the solvent. Before the first TRUEX demonstration test, the solvent was treated with two $0.25 \mathrm{M}$ sodium carbonate scrubs, two water scrubs, and two equilibrations with $0.05 \mathrm{MHNO}_{3}$ (all at $\mathrm{O} / \mathrm{A}=3$ ). After each of the demonstration tests, the solvent was cleaned up using the same sodium carbonate, water, and dilute acid equilibrations; and the americium distribution tests were repeated to determine if any significant degradation of the solvent or CMPO concentration had occurred. In all the tests, the solvent remained consistent throughout, with only small changes in the americium distribution values. Table 4 shows the results from the americium distribution tests for the TRUEX solvent at the various stages throughout the three demonstration tests. After the final design test, a significant amount of plutonium remained in the solvent. Two additional sodium carbonate, water, and dilute $\mathrm{HNO}_{3}$ scrubs were performed to reduce the plutonium content in the used solvent. These results are shown in Table 5. The plutonium concentration in the solvent was reduced by about $40 \%$ after the first scrub and to about $60 \%$ after the second scrub. A similar reduction in the ruthenium content of the used solvent was also noted for the two carbonate scrubs. The plutonium and ruthenium could have been tied up as complexes with the acidic degradation products. No further attempts were made to remove the plutonium from the solvent or any other test to determine the degradation of the solvent. 
Table 4. Americium distribution test results

Distribution coefficients

$$
\mathrm{H}^{+}=0.01 \quad \mathrm{H}^{+}=0.05 \quad \mathrm{H}^{+}=2.0
$$

Fresh solvent after carbonate scrubbing

0.11

0.42

22.6

Solvent after first tracer run

0.08

0.33

17.8

Second tracer run feed after carbonate scrubbing

0.11

0.37

19.2

Solvent after second tracer run

0.21

Design run feed after carbonate scrubbing

0.12

0.37

23.5

Solvent after design nun

0.15

0.76

29.53

Table 5. Cleanup of used TRUEX solvent

\begin{tabular}{|c|c|c|c|c|}
\hline & \multicolumn{2}{|c|}{ Plutonium } & \multicolumn{2}{|c|}{ Ruthenium } \\
\hline & $\overline{\mathrm{mg} / \mathrm{L}}$ & $\overline{\text { Fraction }}$ & $\overline{\mathrm{Bq} / \mathrm{L}}$ & Fraction \\
\hline End of Run 3 & 86 & 1 & $1.8 \mathrm{E} 9$ & 1 \\
\hline First Wash ${ }^{a}$ & 50 & 0.58 & $9.0 \mathrm{E} 8$ & 0.51 \\
\hline Second Wash ${ }^{a}$ & 33 & 0.38 & $6.7 \mathrm{E} 8$ & 0.38 \\
\hline
\end{tabular}

${ }^{a} 0.25 \mathrm{MNa}_{2} \mathrm{CO}_{3}, \mathrm{H}_{2} \mathrm{O}$, and $0.05 M \mathrm{HNO}_{3}$.

\section{GENERIC TRUEX MODEL (GTM) COMPARISONS}

\subsection{GTM PREDICTIONS}

The GTM developed by ANL was used in the design of the flowsheet for the TRUEX demonstration test. Argonne personnel designed the flowsheet based on the constraints (flow rates, O/A ratios obtainable, and fixed 
number of mixer-settler stages) of the SETF equipment and the desired separations in the americium-curium and plutonium products. After the demonstration tests, the actual flow rates and concentrations were input into the GTM Version 3 (3/94), and stage profiles for each of the three demonstration tests were produced. Two main assumptions were necessary in the model inputs. The first was an assumption of the fission product concentrations. These concentrations were based on estimates from the ORIGEN computer model, which predicts the concentrations of various constituents in irradiated materials. Analysis of ${ }^{134,137} \mathrm{Cs},{ }^{90} \mathrm{Sr},{ }^{154,155} \mathrm{Eu}$, and other minor fission products confirmed the predictions based on the ORIGEN model. The second assumption made was that each stage in the mixer-settlers was operating at $100 \%$ extraction efficiency. After the data were collected and analyzed, an extraction efficiency was calculated from the profile and stage samples and was determined to be $\sim 85 \%$.

\subsection{COMPARISON RESULTS}

Comparisons of the model predictions with the data from the demonstration tests for curium are given in Figures 5,6, and 7. Good agreement between the model predictions and the actual concentration data was obtained for the extraction section. In the aqueous scrub sections, the model yielded a good match to the organic concentrations (good material balance) and matched the general trend of the curium in the aqueous phase; however, the aqueous phase concentrations were lower in the model for the two tracer runs, implying some problems with its prediction of $\mathrm{D}$ values or handling oxalate complexing effects present in these runs. In the design run, with the high feed concentration, the match between the model predictions and the data was much better.

In the curium stripping section, good agreement was obtained for the model prediction and the experimental data for the two tracer nuns, but the comparison for the design run showed a much larger deviation. This deviation could possibly be due to the model's prediction which, at the time, neglected nitrate organic scrub section, which, again, implies a problem in the calculation of $D$ values. The problem areas described above for the curium could be due to such things as solvent loading effects, the oxalic acid complexing effects, or the nitrate-metal complex effects, which may need to be adjusted or added in the model.

Figures 8,9 , and 10 show the comparison of the data with model predictions for plutonium. As with the curium, the model prediction yielded a good match to the organic concentrations in the aqueous scrub section (good material balance); however, large differences were present in the aqueous concentrations for this section, especially in the tracer runs. Again, this difference may be caused by the model not properly accounting for oxalate complexing, solvent loading (for the third run), nitrate concentration effects, or the prediction of the D values. Good agreement between the model predictions and the experimental data was obtained for the organic 


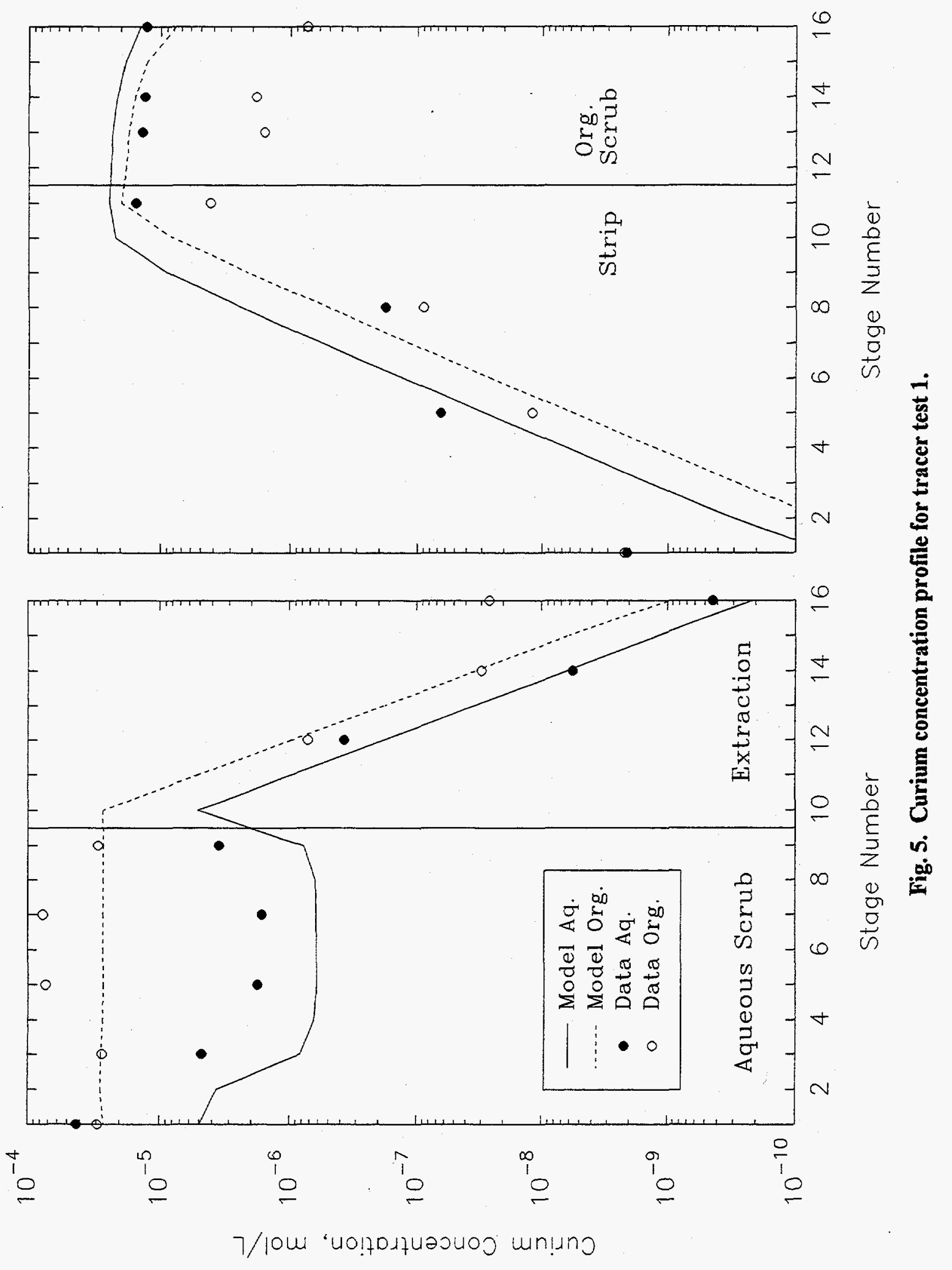




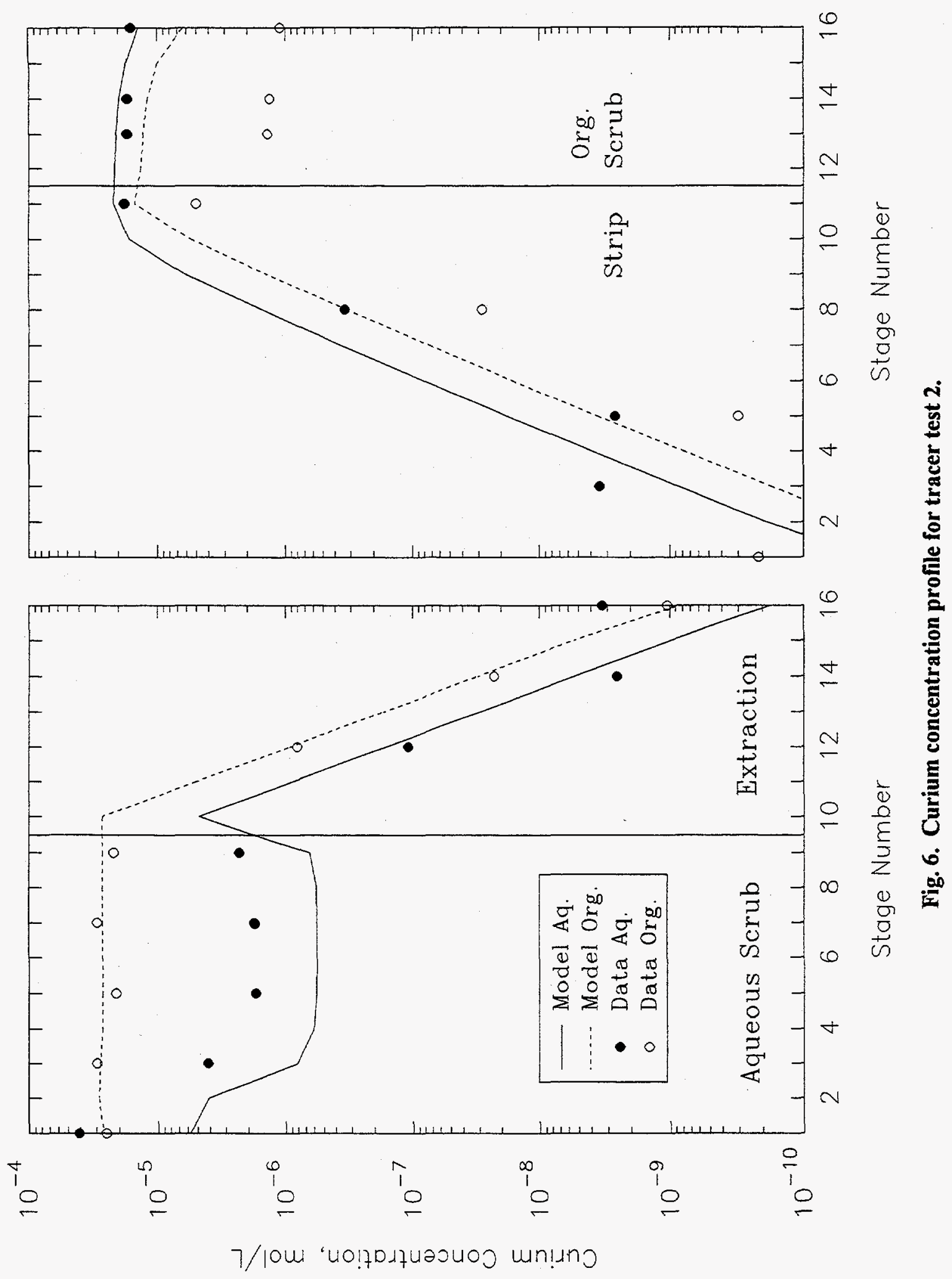




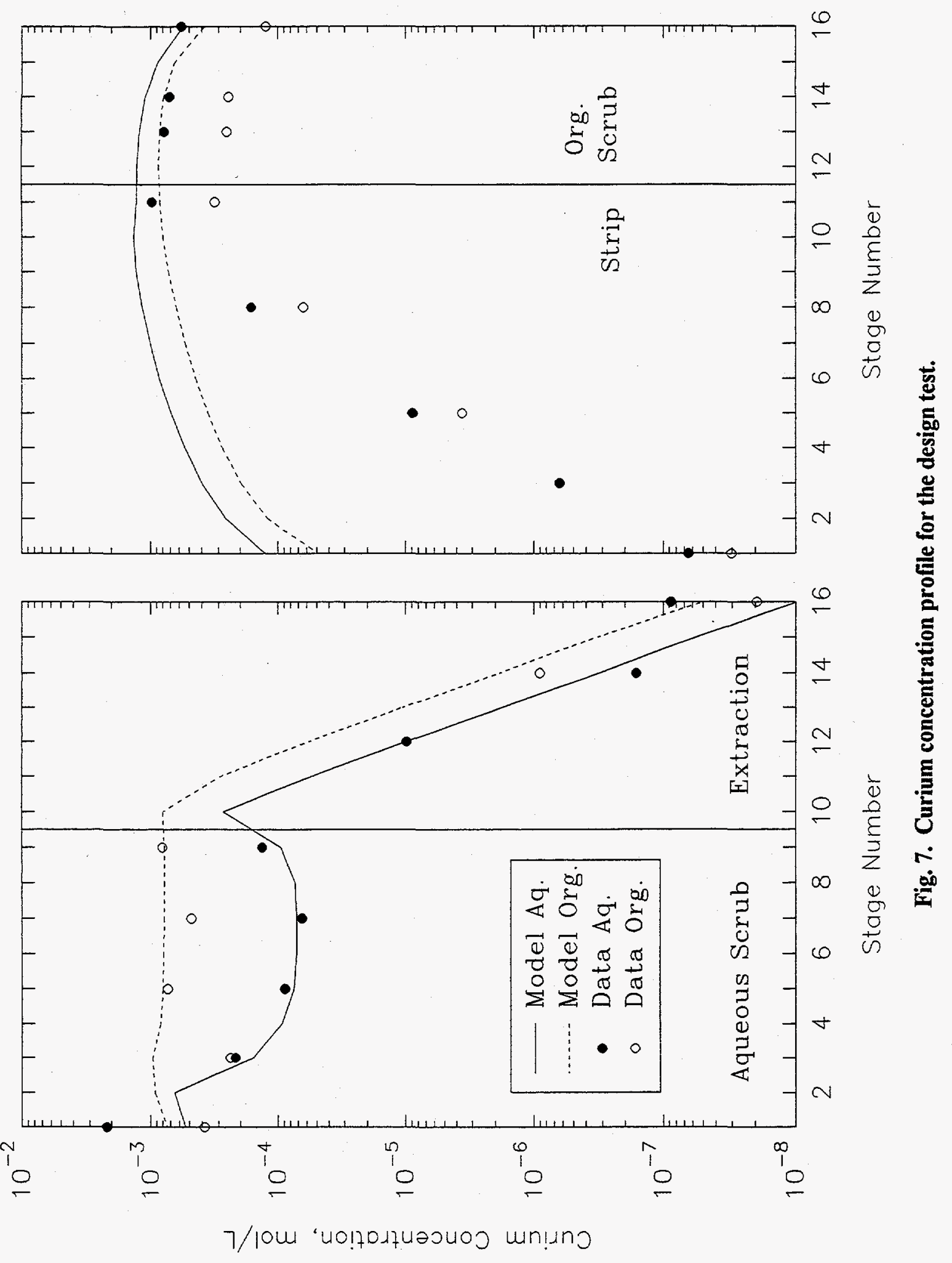




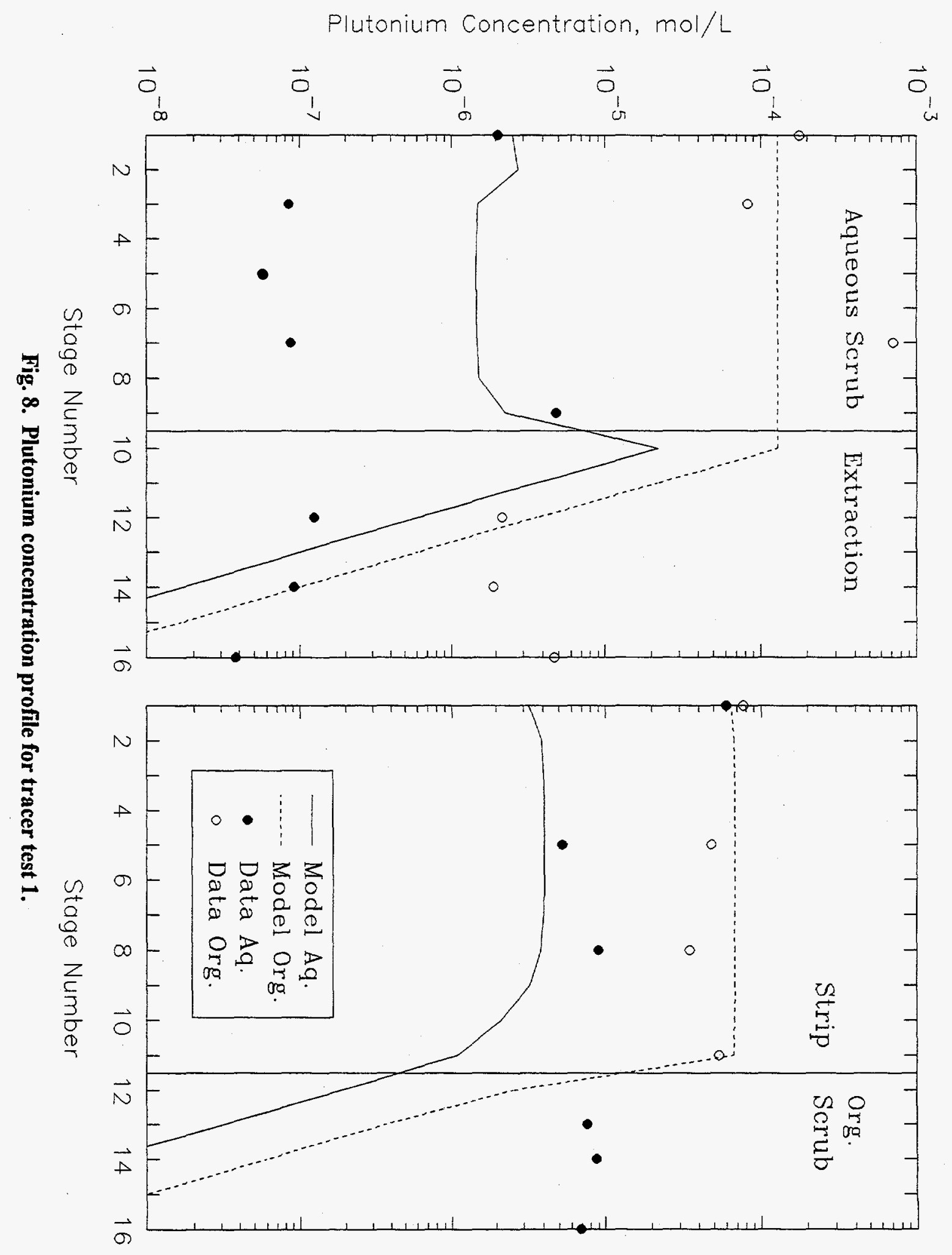




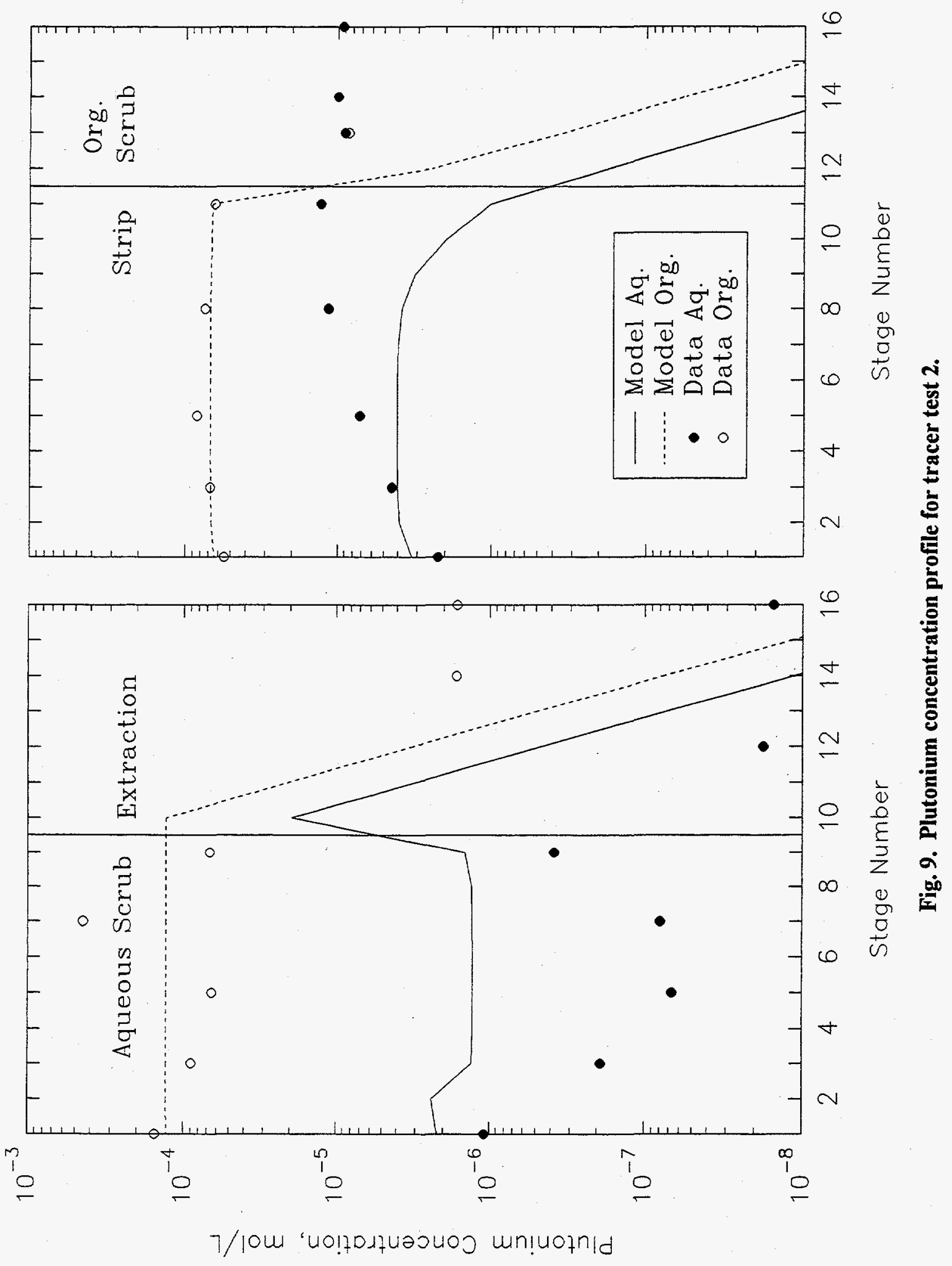




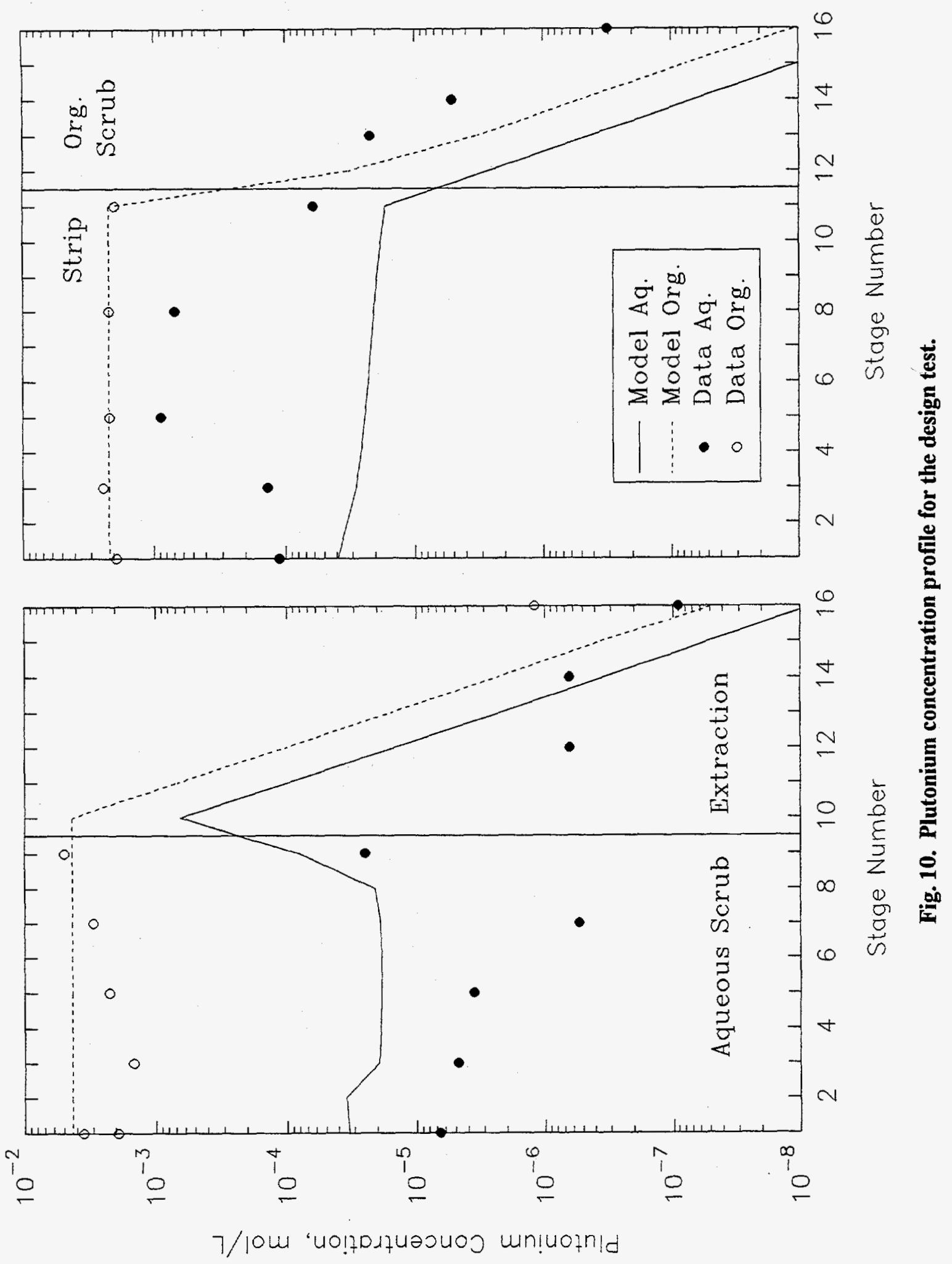


phase concentrations in the americium-curium strip section (good material balance). The model predicted much lower concentrations in the aqueous phase for the organic scrub section for all the runs. The large difference in the two tracer runs was probably due to the excess oxalic acid added in the scrub section for the first tracer run; however, the second run used a lower oxalate concentration and the model should have accounted for the oxalate concentrations. The analysis of low concentrations of plutonium in the presence of high curium may also be the cause of some of the deviations noted. The model was not used to predict the plutonium stripping behavior in the plutonium stripping section.

\section{SUMMARY AND CONCLUSIONS}

The objective to collect data for the TRUEX process from higher activity solutions using the GTM predictions to design the process flowsheet was met. The GTM was improved initially for use in the design for these test nuns. These improvements were the inclusion of stage efficiency for the mixer-settler equipment, the rerouting of solutions to intermediate stages, and the calculation of $D$ values at higher temperatures. All the desired tests were completed with minimal operational problems. The two tracer runs, conducted to test the equipment and minor flowsheet changes, yielded valuable data for the model comparisons.

The design criteria for the americium-curium product and plutonium product were met. The americiumcurium product contained $<0.1 \%$ of the plutonium and the plutonium product contained $<1 \%$ of the americium and curium. There were also low losses of americium, curium, and plutonium to the aqueous raffinate. The major problem area revolved around plutonium stripping. In all three tests, a significant plutonium concentration was present in the waste organic solution. Some additional organic scrubs were performed to remove this plutonium; however, it is believed that this plutonium was tied up as complexes with acidic degradation products. No attempts were made to determine the degradation of the solvent, except for the americium distribution tests described earlier.

Good agreement between the model predictions and the actual curium concentration data was obtained for the extraction sections and also for the organic concentrations in the scrub section, especially for the design run. In the curium stripping section, the best agreement was obtained for the two tracer runs, with the design run showing a larger deviation. This deviation could possibly be due to the model's predictions which, at the time, neglected the effects of nitrate complexing. The results also indicated some problems with the model's prediction of $\mathrm{D}$ values. Good agreement between the model predictions and the actual plutonium concentration data was obtained for the organic concentrations in the aqueous scrub sections, but large deviatations were obtained for the aqueous concentrations. This deviation may have been caused by the model not properly accounting for 
the aqueous concentrations. This deviation may have been caused by the model not properly accounting for oxalate complexing, solvent loading, nitrate concentration effects, or the prediction of $\mathrm{D}$ values.

Several areas for improvements in the GTM were identified in these tests. With these improvements, the model would be more accurate and more useful for a variety of feed solutions. Argonne personnel are in the process of adding the nitrate complexation effects and modifications to the $D$ value calculations to yield better predictions. 


\section{REFERENCES}

1. G. F. Vandegrift, R. A. Leonard, M. J. Steindler, E. P. Horwitz, L. J. Basile, H. Diamond, D. G. Kalina, and L. Kaplan, Transuranic Decontamination of Nitric Acid Solutions by the TRUEX Solvent Extraction Process-Preliminary Development Studies, ANL-84-45, Argonne National Laboratory, 1984.

2. G. F. Vandegrift, J. M. Copple, D. B. Chamberlain, R. A. Leonard, M. C. Regalbuto, D. J. Chaiko, L. Chow, D. R. Fredrickson, R. J. Jaskot, L. Nunez, J. Sedlet, I. R. Tasker, L. E. Trevorrow, and E. H. VanDeventer, The Generic TRUEXModel, Operation Manual for the IBM-PC Compatible and Macintosh Computers, ANL-92/41, Argonne National Laboratory, 1992.

3. L. K. Felker, D. E. Benker, F. R. Chattin, and R. G. Stacy, "Separation of Americium, Curium, and Plutonium from Irradiated Targets," presented at the Eighth Symposium on Separation Science and Technology for Energy Applications, Gatlinburg, Tenn., Oct. 25-28, 1993.

4. E. D. Collins, D. E. Benker, J. E. Bigelow, F. R. Chattin, M. H. Lloyd, L. J. King, R. G. Ross, and H. C. Savage, Solvent Extraction Studies of Coprocessing Flowsheets - Results from Campaigns 1 and 2 of the Solvent Extraction Test Facility (SETF), ORNL/TM-7080, Oak Ridge National Laboratory, July 1982.

5. R. A. Leonard, J. M. Copple, M. C. Regalbuto, D. B. Chamberlain, and G. F. Vandegrift, TRUEX Processing of Mark 42 Targets, letter report, Chemical Technology Division, Argonne National Laboratory, Apr. 30, 1993.

6. J. C. Mailen, "Secondary Purex Solvent Cleanup: Laboratory Development," Nuclear Technology 83 (November 1988).

7. Pui-Kwan Tse, L. Reichley-Yinger, and G. F. Vandegrift, "TRUEX Process Solvent Cleanup with Solid Sorbents," Separation Science and Technology 25(13-15), 1763-1775 (1990). 


\section{ACKNOWLEDGMENTS}

The authors wish to acknowledge the support of the Underground Storage Tank Integrated Demonstration Program under the Office of Technology Development and the Defense Production and Energy Research Programs of the Department of Energy for this work. The support of a number of technicians, analysts, and craftsmen involved in the preparation of the SETF equipment, operation of the equipment, and sample analysis was appreciated, as well as the help of Sonia Lay in the preparation of the manuscript for publication. 


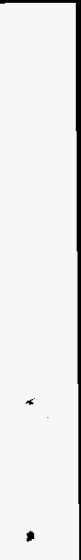


APPENDIX A

TABLES OF ANALYTICAL DATA FOR THE TRUEX TESTS 


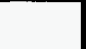




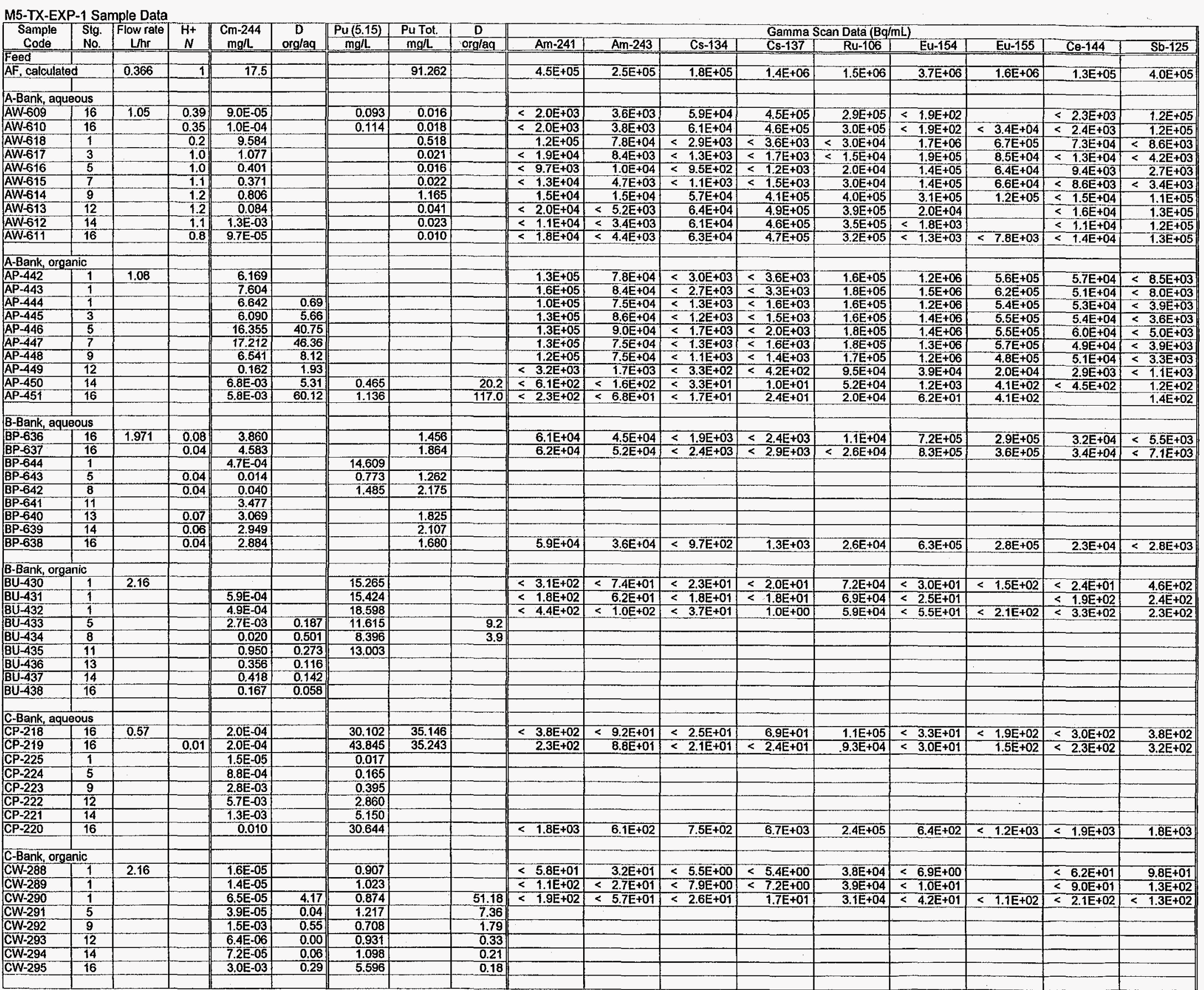


M5-TX-EXP-2 Sample Data
Sample

\begin{tabular}{|c|c|c|c|c|c|c|c|c|c|c|c|c|c|c|c|c|c|}
\hline $\begin{array}{c}\begin{array}{c}\text { Sample } \\
\text { Code }\end{array} \\
\end{array}$ & $\begin{array}{l}\text { Stg. } \\
\text { No. }\end{array}$ & $\begin{array}{l}\text { Fow rat } \\
\text { Lin }\end{array}$ & $\begin{array}{l}\mathrm{H}+ \\
\mathrm{N} \\
\end{array}$ & $\begin{array}{c}\mathrm{Cm}-244 \\
\mathrm{mg} / 4 \\
\end{array}$ & $\begin{array}{c}D \\
\text { orglaq }\end{array}$ & $\frac{\overline{P u(5.15)}}{\mathrm{mgl}}$ & $\begin{array}{l}\text { Putot. } \\
\text { mght }\end{array}$ & $\begin{array}{c}0 \\
\text { orglag }\end{array}$ & $\mathrm{Am}-241$ & Am-243 & Cs-134 & $\begin{array}{l}\text { Gammase } \\
\text { Cs-137 } \\
\end{array}$ & $\begin{array}{r}\text { Data (Bg/n } \\
\text { Ru-106 }\end{array}$ & Eu-154 & $E u-155$ & Ce.144 & Sb. 125 \\
\hline $\begin{array}{l}\text { Feed } \\
A F \text {, calculater } \\
\end{array}$ & & 0.365 & 1 & 17.5 & & & 91.262 & & $4.5 E+05$ & $2.5 E+05$ & $1.8 E+05$ & $1.4 E+06$ & $1.5 E+08$ & $3.7 E+06$ & $1.6 \mathrm{E}+0 \overline{6}$ & $1.3 E+05$ & $4.0 \mathrm{E}+05$ \\
\hline & & & & & & & & & & & & & & & & & \\
\hline AW-620 & & 1.11 & 0.90 & $7.7 E-05$ & & 0.090 & 0.004 & & $\leq 8.2 E+03$ & $<2.0 \mathrm{E}+03$ & $5.8 \mathrm{E}+04$ & $4.4 E+05$ & $2.6 E+05$ & $<5.0 \mathrm{E}+02$ & $<3.5 E+01$ & $\begin{array}{ll}<6 & 6.3 \mathrm{E}+02\end{array}$ & $1.1 \mathrm{E}+05$ \\
\hline$A W-621$ & 16 & & 0.82 & $1.3 E-03$ & & & 0.155 & & $<2.5 E+03$ & $<7.5 E+02$ & $2.9 E+04$ & $2.3 E+05$ & $1.3 E+05$ & $<3.5 \mathrm{E}+02$ & & $<7.5 E+03$ & $5.5 \mathrm{E}+04$ \\
\hline$\overline{A W-629}$ & $\frac{1}{2}$ & & 0.21 & 9.157 & & & 0.261 & & $2.3 E+04$ & $6.6 E+03$ & $<8.0 \mathrm{E}+02$ & $<1.0 E+03$ & $9.9 E+03$ & $1.7 E+05$ & $7.6 E+04$ & $6.9 \mathrm{E}+03$ & $<2.3 E+03$ \\
\hline \begin{tabular}{|l|l|}
$A W-628$ \\
\end{tabular} & 3 & & 0.23 & 0.927 & & & 0.046 & & $1.3 E+05$ & $7.3 E+04$ & $\leq 2.5 E+03$ & $<3.1 E+03$ & $\leq 2.6 E+04$ & $1.7 E+06$ & $6.9 E+05$ & $6.1 E+04$ & $<7.2 \mathrm{E}+03$ \\
\hline$A W-627$ & 5 & & 0.28 & 0.392 & & & 0.016 & & $3.5 \mathrm{E}+03$ & $2.8 E+03$ & $<5.9 \mathrm{E}+02$ & $<8.5 \mathrm{E}+02$ & $2.4 E+04$ & $8.3 E+04$ & $3.8 \mathrm{E}+04$ & $<4.2 E+03$ & $<1.7 \mathrm{E}+03$ \\
\hline AW-626 & 7 & & 0.38 & 0.401 & & & 0.019 & & $\leq 7.0 E+03$ & $4.0 E+03$ & $<6.6 \mathrm{E}+02$ & $<9.0 \mathrm{E}+02$ & $2.5 \mathrm{E}+04$ & $8.5 \mathrm{E}+04$ & $4.1 \mathrm{E}+04$ & $<4.5 \mathrm{E}+03$ & $<1.8 \mathrm{E}+03$ \\
\hline 625 & 9 & & 0.47 & 0.529 & & & 0.092 & & $1.4 E+04$ & $5.6 \mathrm{E}+03$ & $<6.8 \mathrm{E}+02$ & $8.7 \mathrm{E}+02$ & $5.1 E+04$ & $1.2 E+05$ & $5.4 E+04$ & $6.5 E+03$ & $<2.0 E+03$ \\
\hline 624 & 12 & & 0.66 & 0.024 & & & 0.004 & & $\leq 1.3 E+04$ & $<3.2 E+03$ & $5.6 \mathrm{E}+04$ & $4.4 E+05$ & $3.3 E+05$ & $5.8 E+03$ & & $<9.7 E+03$ & $1.1 \mathrm{E}+0 \mathrm{5}$ \\
\hline AW-623 & 14 & & 0.56 & 5.7E-04 & & & 0.002 & & $<8.4 E+03$ & $<2.5 E+03$ & $4.9 \mathrm{E}+05$ & $4.9 E+05$ & $3.2 E+05$ & $<1.1 \mathrm{E}+03$ & & $<8.1 E+03$ & $1.2 \mathrm{E}+05$ \\
\hline$A W-622$ & 16 & & 0.42 & 7.4E-04 & & & 0.004 & & $<1.3 E+04$ & $<3.1 E+03$ & $6.0 E+04$ & $4.8 E+05$ & $2.8 \mathrm{E}+05$ & $<1.3 E+03$ & & $<9.5 \mathrm{E}+03$ & $1.2 E+05$ \\
\hline Ian & & & & & & & & & & & & & & & & & \\
\hline-452 & 1 & 1.08 & & 6.546 & & & & & $8.2 \mathrm{E}+05$ & $4.0 E+05$ & $<1.1 \mathrm{E}+04$ & $<1.4 \mathrm{E}+04$ & $1.0 E+06$ & $6.7 E+06$ & $3.0 E+06$ & $2.8 E+05$ & $<3.2 E+04$ \\
\hline 45 & 1 & & & 5.689 & & & & & $1.4 E+05$ & $7.5 \mathrm{E}+04$ & $<2.2 \mathrm{E}+03$ & $<2.8 \mathrm{E}+03$ & $1.8 \mathrm{E}+05$ & $1.3 \mathrm{E}+06$ & $5.8 \mathrm{E}+05$ & $6.7 \bar{E}+04$ & $<6.3 \mathrm{E}+03$ \\
\hline AP-454 & 1 & & & 5.588 & 0.61 & & & & $1.3 E+05$ & $7.6 \mathrm{E}+04$ & $<1.3 \mathrm{E}+03$ & $<1.6 \mathrm{E}+03$ & $1.8 \mathrm{E}+05$ & $1.3 E+06$ & $5.7 \mathrm{E}+05$ & $5.3 E+04$ & $<4.0 \mathrm{E}+03$ \\
\hline AP-455 & 3 & & & 6.548 & 7.06 & & & & $1.4 \mathrm{E}+05$ & $9.1 \mathrm{E}+04$ & $<1.3 \mathrm{E}+03$ & $<1.5 \mathrm{E}+03$ & $1.8 \mathrm{E}+05$ & $1.6 \mathrm{E}+06$ & $6.1 \mathrm{E}+05$ & $5.8 E+04$ & $<3.8 \mathrm{E}+03$ \\
\hline$A P-456$ & 5 & & $\ldots$ & 4.771 & 12.16 & & & & $1.2 \mathrm{E}+05$ & $8.2 \mathrm{E}+04$ & $<1.4 \mathrm{E}+03$ & $<1.7 \mathrm{E}+03$ & $2.0 \bar{E}+05$ & $1.4 \mathrm{E}+06$ & $6.0 \mathrm{E}+05$ & $4.6 E+04$ & $<4.1 \mathrm{E}+03$ \\
\hline AP-457 & 7 & & Z & 6.522 & 16.25 & & & & $1.2 E+05$ & $7.3 \mathrm{E}+04$ & $<8.1 E+02$ & $<9.9 E+02$ & $1.9 \mathrm{E}+05$ & $1.3 E+06$ & $5.5 E+05$ & $4.9 \mathrm{E}+04$ & $<2.4 E+03$ \\
\hline$P-458$ & 9 & & & 4.939 & 9.34 & & & - & $1.2 \mathrm{E}+05$ & $7.6 \mathrm{E}+04$ & $<1.1 \mathrm{E}+03$ & $<1.4 \mathrm{E}+03$ & $2.0 E+05$ & $1.3 E+06$ & $5.0 E+05$ & $4.4 E+04$ & a $3,3 \mathrm{E}+03$ \\
\hline & 12 & & & 0.181 & 7.41 & & & & $1.8 \mathrm{E}+03$ & $1.0 E+03$ & $<1.3 \mathrm{E}+02$ & $<1.6 \mathrm{E}+02$ & $6.6 \mathrm{E}+04$ & $3.8 \mathrm{E}+04$ & $1.7 E+04$ & $1.1 \mathrm{E}+03$ & $<5.2 E+02$ \\
\hline 80 & 14 & & & $5.2 E-03$ & 9.08 & 0.396 & & 170 & $<1.5 \mathrm{E}+02$ & $8.4 E+01$ & $<1.3 \mathrm{E}+01$ & $4.1 E+01$ & $6.6 \mathrm{E}+04$ & $1.1 \mathrm{E}+03$ & $4.0 \mathrm{E}+02$ & $1.4 E+02$ & $1.8 \mathrm{E}+02$ \\
\hline AP-461 & 16 & & & $2.4 E .04$ & 0.32 & 0.395 & & 102 & $<8.7 E+00$ & $2.0 \mathrm{E}+01$ & $7.6 \mathrm{E}+00$ & $2.9 \mathrm{E}+01$ & $3.3 E+04$ & $3.8 \mathrm{E}+01$ & & $<\quad 8.2 E+01$ & $1.2 E+02$ \\
\hline B-Bant & & & & & & & & & & & & & & & & & \\
\hline $\mathrm{BP}-646$ & $\frac{03}{16}$ & 1.99 & 0.06 & 3.019 & & & 2.233 & 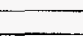 & $3.2 E+03$ & $1.7 E+03$ & $<6.5 E+01$ & $<8.0 \mathrm{E}+01$ & $7.3 \mathrm{E}+02$ & $2.9 E+04$ & $1.3 E+04$ & $2.3 E+04$ & $<1.9 E$ \\
\hline $8 P .647$ & 16 & & 0.06 & 3.126 & & & 2.447 & & $6.4 E+04$ & $3.9 \mathrm{E}+04$ & $<1.4 \mathrm{E}+03$ & $<1.7 \mathrm{E}+03$ & $1.1 \mathrm{E}+04$ & $6.3 \mathrm{E}+05$ & $2.7 E+05$ & $2.2 E+04$ & $<3.9 E+03$ \\
\hline BP. 655 & 1 & & & $8.4 E-06$ & & & 0.535 & & & & & & & & & & \\
\hline BP-654 & 3 & & & $7.8 E-04$ & & & 1.058 & & & & & & & & & & \\
\hline BP-653 & 5 & & & $5.8 \mathrm{E}-04$ & & 1.923 & 1.738 & & & & & & & & & & \\
\hline BP. 652 & 8 & & & 0.075 & & 3,903 & 2.816 & & & & & & & & & & \\
\hline BP-651 & 11 & & & 4.018 & & & 3.194 & & & & & & & & & & \\
\hline BP. -650 & 13 & & & 3.849 & & & 2.165 & & & & & & & & & & \\
\hline$B P-649$ & 14 & & & 3.815 & & & 2.437 & & & & & & & & & & \\
\hline BP-648 & 16 & & 0.06 & 3.620 & & & 2.262 & & $6.6 \mathrm{E}+04$ & $3.7 E+04$ & $<6.5 E+02$ & $<8.2 E+02$ & $1.9 E+04$ & $6.7 E+05$ & $2.9 \mathrm{E}+05$ & $2.3 E+04$ & $<1.9 \mathrm{E}+03$ \\
\hline & & & & & & & & & & & & & & & & & \\
\hline BU-439 & $\frac{1}{1}$ & 2.17 & & 0.000 & & 15.533 & & & $<5.2 E+02$ & $<1.2 E+02$ & $<4.5 E+01$ & $<2.5 E+01$ & $9.0 \mathrm{E}+05$ & $<8.2 E+01$ & $<2.5 \mathrm{E}+02$ & $<4.0 \mathrm{E}+02$ & $2.4 \mathrm{E}+02$ \\
\hline $80-440$ & 1 & & & $5.9 E-05$ & & 18.187 & & & $<5.2 \mathrm{E}+02$ & $<1.2 E+02$ & $<4.1 \mathrm{E}+01$ & $<4.7 \mathrm{E}+01$ & $8.4 E+04$ & $<7.0 \mathrm{E}+01$ & $<2.5 \mathrm{E}+02$ & & $\frac{2.4 E+02}{2.0 E+02}$ \\
\hline-441 & 1 & & & $4.8 E-05$ & 5.686 & 13.238 & & 24.75 & $\leq 3.6 \mathrm{E}+02$ & $<1.5 E+02$ & $<2.9 E+01$ & $<3.0 \mathrm{E}+01$ & $8.3 E+04$ & $<4.4 E+01$ & $<1.7 E+02$ & $\leq 2.7 \mathrm{E}+02$ & $3.2 E+02$ \\
\hline & 3 & & & $5.8 \mathrm{E}-06$ & 0.007 & 16.482 & & 15.57 & & & & & & & & & \\
\hline $80-4$ & 5 & & & $6.8 E-05$ & 0.116 & 20.222 & & 11.64 & & & & & & & & & \\
\hline & 8 & & & 0.006 & 0.085 & 17.858 & & 6.34 & & & & & & & & & \\
\hline BU & 11 & & & 1.118 & 0.278 & 15.371 & & 4.81 & & & & & & & & & \\
\hline & 13 & & & & & & & & & & & & & & & & \\
\hline & 14 & & & 0.298 & 0.078 & & & & & & & & & & & & \\
\hline BU-448 & 16 & & & 0.248 & 0.0 & & & & & & & & & & & & \\
\hline -Bank & OUS- & & & & & & & & & & & & & & & & \\
\hline dalon, aque & $\frac{040}{16}$ & 1.21 & 0.08 & $3.2 E-06$ & & 31.534 & 31.942 & & $<4.7 E+02$ & $<4.8 E+01$ & $<2.0 E+01$ & $2.9 \mathrm{E}+01$ & $2.1 \mathrm{E}+04$ & $<5.2 \mathrm{E}+01$ & $<1.0 \mathrm{E}+02$ & $<1.7 \mathrm{E}+02$ & $<1.1 \mathrm{E}+02$ \\
\hline CP.22 & $1 \overline{6}$ & & & $3.3 E-06$ & & 33.084 & 32.039 & & $<1.8 E+02$ & $<5.05+01$ & $<1.3 \mathrm{E}+03$ & $3.1 E+01$ & $2.2 E+04$ & $<3.2 E+01$ & $=1.1 E+02$ & $<\quad 1.8 \mathrm{E}+02$ & $<1.1 \mathrm{E}+02$ \\
\hline tor & 1 & & & 2. & & & 0.044 & & & & & & & & & & \\
\hline & 3 & & & $3.1 E-04$ & & 0.165 & 0.191 & & & & & & & & & & \\
\hline CP-234 & 5 & & & 5.8 & & & & & & & & & & & & & \\
\hline$C P-233$ & 9 & & & $8,5 E-05$ & & 17 & & & & & & & & & & & \\
\hline$C P-23$ & 12 & & & 3.6 & & 8. & & & & & & & & & & & \\
\hline CP-231 & 14 & & & $1.0 \mathrm{E}-04$ & & 14. & & & & & & & & & & & \\
\hline CP. 230 & 16 & 0.066 & & $5.0 \mathrm{E}-04$ & & 30.132 & & & $<2.7 E+02$ & $\leq 7.0 \mathrm{E}+01$ & $<2.4 E+01$ & $2.3 E+01$ & $2.3 E+04$ & $<8.0 \mathrm{E}+01$ & $<1.4 E+02$ & $<2.2 E+02$ & $<1.3 E+02$ \\
\hline & & & & & & & & & & & & & & & & & \\
\hline $\mathrm{CW}$ & 1 & 2.17 & & $2.4 \mathrm{E}-05$ & & 0.189 & & & $<4.6 E+02$ & $<1.1 \mathrm{E}+02$ & $<4.1 E+01$ & $<4.5 E+01$ & $7.1 E+04$ & $<5.5 \mathrm{E}+01$ & $<2.2 \mathrm{E}+02$ & $<3.5 E+02$ & $<2.2 E+02$ \\
\hline & 1 & & & $4.6 \mathrm{E}-04$ & & & & & $<4.7 \bar{E}+02$ & $\overline{5} .9 \mathrm{E}+01$ & $<4.0 \mathrm{E}+01$ & $<4.5 \mathrm{E}+01$ & $6.9 E+04$ & $<8.4 \mathrm{E}+01$ & & $<3.6 \mathrm{E}+02$ & $<2.2 E+02$ \\
\hline & 1 & & & $2.9 E-05$ & 1.418 & & & 8.40 & $<8.3 \mathrm{E}+01$ & $<2.4 E+01$ & $<9.3 \mathrm{E}+00$ & $<9.3 \mathrm{E}+00$ & $6.4 E+04$ & $<1.5 E+01$ & & $<8.6 E+01$ & $1.7 \mathrm{E}+02$ \\
\hline & 3 & & & 2.5 & 0. & & & 1.52 & & & & & & & & & \\
\hline & 5 & & & $4.6 E-05$ & & & & 0. & & & & & & & & & \\
\hline CI & 9 & & & 7.8 & 0. & 0. & & U. & & & & & & & & & \\
\hline & 12 & & & 5.21 & 0. & & & & & & & & & & & & \\
\hline$C W-306$ & 14 & & & $4.6 \mathrm{E}-05$ & 0.451 & 4.803 & & 0.34 & & & & & & & & & \\
\hline CW-307 & 16 & & & 4.3E-05 & 0.085 & 11.987 & & 0.40 & & & & & & & & & \\
\hline & & & & & & & & & & & & & & & & & \\
\hline
\end{tabular}




\begin{tabular}{|c|c|c|c|c|c|c|c|c|c|c|c|c|c|c|c|c|c|}
\hline Sample & Stg. & Flow rate & $\mathrm{H}+$ & $\mathrm{Cm}-244$ & D & $P u(5.15)$ & Pu tot. & $D$ & & & & Gamma S & an Dala $(\mathrm{Bg} / \mathrm{m}$ & & & & \\
\hline Code & No. & $\mathrm{Lhr}$ & $N$ & $\mathrm{mgh}$ & orglaq & $\mathrm{mgh}$ & $\mathrm{mg} \Omega$ & orglaq & Am-241 & Am-243 & Cs-134 & Cs-137 & Ru-106 & Eu-154 & Eu-155 & $\mathrm{Ce}+144$ & $\mathrm{Sb}-125$ \\
\hline \begin{tabular}{|l|} 
Feed \\
Af, calculatec
\end{tabular} & & 0.365 & 1 & 469.8 & & & 2980.6 & & $1.4 E+07$ & $6.0 E+06$ & $4.8 E+06$ & $3.7 E+07$ & $3.5 E+07$ & $9.7 E+07$ & $4.3 E+07$ & & $<9.7 E+05$ \\
\hline AF, calculate & & & & & & & & & & & & & & & & & D \\
\hline $\bar{A}$-Bank, aque & & & & & & & & & & & & & & & & & \\
\hline$A W-632$ & 16 & 1.052 & 0.49 & $1.5 \mathrm{E}-03$ & & & 0.010 & & $<1.0 \mathrm{E}+05$ & $<2.9 E+04$ & $1.4 E+06$ & $1.2 E+07$ & $5.7 E+06$ & $<1.0 \mathrm{E}+05$ & & & $1.3 \mathrm{E}+05$ \\
\hline AW- 633 & 16 & 1.002 & 0.47 & $1.8 \mathrm{E}-03$ & & & 0.123 & & $\leq 6.0 \mathrm{E}+04$ & $<1.8 \mathrm{E}+04$ & $\begin{array}{r}1.4 \mathrm{E}+06 \\
\end{array}$ & $1.1 \mathrm{E}+07$ & $5.6 \mathrm{E}+06$ & $<6.2 \mathrm{E}+03$ & $<6.5 \mathrm{E}+04$ & & $4.0 \mathrm{E}+04$ \\
\hline AW-641 & 1 & & 0.16 & 490.53 & & & 1.597 & & $3.7 E+06$ & $1.8 \mathrm{E}+06$ & $<3.2 \mathrm{E}+04$ & $<4.0 \mathrm{E}+04$ & $<3.3 \mathrm{E}+05$ & $4.3 \mathrm{E}+07$ & $1.7 \mathrm{E}+07$ & & $<9.5 E+04$ \\
\hline AW-640 & 3 & 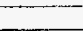 & 0.21 & 49.15 & & & 1.152 & & $6.5 \mathrm{E}+05$ & $4.4 E+05$ & $<9.7 E+03$ & $<1.2 \mathrm{E}+04$ & $3.9 \mathrm{E}+05$ & $1.1 E+07$ & $4.8 \mathrm{E}+06$ & & $<2.9 \mathrm{E}+04$ \\
\hline AW-639 & 5 & & 0.31 & 19.66 & & & 0.873 & & $3.9 \mathrm{E}+05$ & $2.2 \mathrm{E}+05$ & $<7.9 \mathrm{E}+03$ & $<9.6 \mathrm{E}+03$ & $6.2 \mathrm{E}+05$ & $5.4 E+06$ & $2.3 \mathrm{E}+06$ & & $<2.3 \mathrm{E}+04$ \\
\hline AW-638 & 7 & & 0.36 & 14.66 & & & 0.131 & & $3.0 E+05$ & $1.5 \mathrm{E}+05$ & $<6.8 \mathrm{E}+03$ & $<8.2 \mathrm{E}+03$ & $7.7 E+05$ & $4.2 E+06$ & $1.7 \mathrm{E}+06$ & & $<2.0 E+04$ \\
\hline AW- 637 & 9 & & 0.79 & 29.83 & & & 6.001 & & $4.3 E+05$ & $2.5 E+05$ & $<6.7 \mathrm{E}+03$ & $1.2 \mathrm{E}+04$ & $1.4 E+06$ & $5.7 \mathrm{E}+06$ & & & $<1.9 E+04$ \\
\hline AW-636 & 12 & & 0.93 & 2.21 & & & 0.155 & & $<1.0 E+05$ & $2.7 E+05$ & $1.4 \mathrm{E}+06$ & $1.2 E+07$ & $7.7 E+06$ & $4.4 E+05$ & $1.8 \mathrm{E}+05$ & & - 1020 ? \\
\hline AW-635 & 14 & & 0.81 & $3.7 \mathrm{E}-02$ & & & 0.155 & & $<6.1 E+04$ & $<1.8 \mathrm{E}+04$ & $1.4 E+06$ & $1.1 \mathrm{E}+07$ & $6.7 E+06$ & $<8,8 \mathrm{E}+03$ & 1.0LTOS & & $9.5 \bar{E}+04$ \\
\hline AW-634 & 16 & & 0.48 & $2.0 \mathrm{E}-02$ & & & 0.022 & & $<9.6 E+04$ & $<4.1 E+04$ & $1.5 E+06$ & $1.2 E+07$ & $6.0 \mathrm{E}+06$ & $<7.9 E+03$ & $<4.5 E+04$ & & $8.1 \mathrm{E}+04$ \\
\hline $\bar{A}-$ Bank, orgal & & & & & & & & & & & & & & & & & \\
\hline $\mid$\begin{tabular}{|l} 
A-Bank, orgal \\
AP- 462
\end{tabular} & 1 & 1.01 & & 0.449 & & 4.521 & & & $8.2 E+04$ & $4.2 E+04$ & $<4.7 E+03$ & $<6.5 \mathrm{E}+03$ & $5.9 E+04$ & $1.1 E+06$ & $5.1 \mathrm{E}+05$ & & \\
\hline AP- 463 & 1 & & & 85.94 & & 858.99 & & & $1.9 \mathrm{E}+06$ & $1.2 \mathrm{E}+06$ & $<1.5 \mathrm{E}+04$ & $<1.9 \mathrm{E}+04$ & $4.3 E+06$ & $2.3 E+07$ & $8.8 E+06$ & & $<\frac{1.3 E+04}{4.6 E+04}$ \\
\hline AP-464 & 1 & & & & & & & & & & & & & & & & \\
\hline$A P-465$ & 3 & & & 53.91 & 1.097 & & & & $2.2 E+06$ & $1.2 E+06$ & $<3.9 E+04$ & $<4.9 \mathrm{E}+04$ & $1.5 \mathrm{E}+06$ & $2.3 E+07$ & $1.0 E+07$ & & $<1.2 \mathrm{E}+0 \overline{5}$ \\
\hline AP-466 & 5 & & & 163.21 & 8.301 & & & & $3.3 \mathrm{E}+06$ & $1.9 \mathrm{E}+06$ & $<4.0 \mathrm{E}+04$ & $<4.8 E+04$ & $4.3 \mathrm{E}+06$ & $3.5 \mathrm{E}+07$ & $1.4 \mathrm{E}+07$ & & $<1.1 \mathrm{E}+05$ \\
\hline AP-467 & 7 & & & 107.60 & 7.338 & & & & $3.4 \mathrm{E}+06$ & $1.6 \mathrm{E}+06$ & $<4.7 \mathrm{E}+04$ & $<5.7 \mathrm{E}+04$ & $3.9 E+06$ & $3.3 E+07$ & $1.4 E+07$ & & $<1.4 E+05$ \\
\hline AP-468 & 9 & & & 182.42 & 6.115 & & & & $3.2 \mathrm{E}+06$ & $1.8 E+06$ & $<4.7 E+04$ & $<5.7 \mathrm{E}+04$ & $3.6 E+06$ & $3.3 \mathrm{E}+07$ & $1.4 \mathrm{E}+07$ & & $<1.3 E+05$ \\
\hline AP- 469 & 12 & & & & & & & & & & & & & & & & \\
\hline AP-470 & 14 & & & 2.0E-01 & 5.502 & & & & $<3.3 \mathrm{E}+04$ & $8.4 E+03$ & $\leq 2.4 \mathrm{E}+03$ & & $1.5 E+06$ & $5.5 E+04$ & $2.4 E+04$ & & $<1.1 E+04$ \\
\hline AP-471 & 16 & & & $4.3 \mathrm{E}-03$ & 0.221 & 0.292 & & 13.3 & $\leq 1.9 \mathrm{E}+04$ & $<4.5 E+03$ & $<-1.8 \mathrm{E}+03$ & $<$ & $6.3 E+05$ & $<6.4 E+03$ & $<9.8 \mathrm{E}+03$ & & $<8.4 E+03$ \\
\hline B-Bank & & & & & & & & & & & & & & & & & \\
\hline $\begin{array}{l}\text { B-Bank, aque } \\
\mathrm{BP}-658\end{array}$ & $\frac{\text { ous }}{16}$ & 1.309 & 0.07 & 139.10 & & & 0.097 & & $3.0 E+06$ & $1.8 E+06$ & $<2.0 E+04$ & $<2.5 \mathrm{E}+04$ & $<2.1 E+05$ & $2.7 \mathrm{E}+07$ & & & $<5.5 E+04$ \\
\hline BP-659 & $\frac{16}{16}$ & 1.309 & 0.07 & 142.95 & & & 0.018 & & $2.5 E+06$ & $1.4 E+06$ & $<2.1 \mathrm{E}+04$ & $<2.6 \mathrm{E}+04$ & $<\frac{2.7 E+00}{2.2 E+05}$ & $\frac{2.1 E+01}{2.4 E+07}$ & $1.0 \mathrm{E}+07$ & & $-<\frac{5.5 E+04}{<.1 E+04}$ \\
\hline BP-667 & 1 & & 0.04 & 0.014 & & & 27.184 & & & & & & & & & & \\
\hline BP-666 & 3 & & & 0.143 & & & 33.398 & & & & & & & & & & 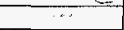 \\
\hline BP-665 & 5 & & 0.04 & 1.97 & & $100 . \overline{47}$ & 214.563 & & & & & & & & & & $\cdots$ \\
\hline$B P-664$ & 8 & & & 36.67 & & & 168.932 & & & & & & & & & & \\
\hline BP-663 & 11 & & 0.09 & 219.08 & & & 14.757 & & & & & & & & & & \\
\hline BP-662 & 13 & & & 174.84 & & & 5.340 & & & & & & & & & & \\
\hline BP-661 & 14 & & 0.07 & 159.42 & & & 1.252 & & & & & & & & & & \\
\hline BP-660 & 16 & & 0.07 & 128.53 & & & 0.074 & & $1.5 E+06$ & $1.5 \mathrm{E}+06$ & $1.9 E+04$ & $2.3 E+04$ & $<2.0 E+05$ & $2.4 E+07$ & $9.6 \mathrm{E}+06$ & & $5.2 E+04$ \\
\hline - & & & & & & & & & & & & & & & & & \\
\hline$\frac{B-a}{B U-449}$ & & 21 & & 0.007 & & 482.92 & & & $=3.0 E+04$ & $<7.3 \mathrm{E}+03$ & $<2.4 \mathrm{E}+03$ & $<3.0 E+03$ & $21 E+06$ & $<57 E+03$ & & & $<12 \mathrm{E}+04$ \\
\hline BU-450 & $\frac{1}{1}$ & & & $5.0 \mathrm{E} \cdot 03$ & & 457.48 & & & $<8.8 \mathrm{E}+03$ & $<2.2 \mathrm{E}+03$ & $<6.7 \mathrm{E}+02$ & $<6.7 \mathrm{E}+02$ & $2.2 E+06$ & $<1.2 \mathrm{E}+03$ & & & $7.4 E+03$ \\
\hline BU. -451 & 1 & & & $6.8 \mathrm{E}-03$ & 0.469 & 464.80 & & 17.1 & $\begin{array}{r}3.8 E+03 \\
\end{array}$ & $9.8 \mathrm{E}+02$ & $<2.8 E+02$ & $<2.7 E+02$ & $2.3 E+06$ & $9.1 \mathrm{E}+02$ & & & $5.6 \mathrm{E}+03$ \\
\hline 5 & 3 & & & & & 583.21 & & 17.5 & & & & & & & & & \\
\hline BU-453 & 5 & & & $8.1 \mathrm{E}-01$ & 0.412 & 523.14 & & 2.4 & & & & & & & & & \\
\hline BU-454 & 8 & & & 14.212 & 0.388 & 526.37 & & 3.1 & & & & & & & & & \\
\hline BU-455 & 11 & & & 73.839 & 0.337 & 475.78 & & 32.2 & & & & & & & & & \\
\hline J-456 & 13 & & & 57.437 & 0.329 & & & & & & & & & & & & \\
\hline BU-458 & 16 & & & 28.040 & 0.218 & & & & & & & & & & & & \\
\hline & & & & & & & & & & & & & & & & & \\
\hline C-Bank, aque & & & & & & & & & & & & & & & & & \\
\hline CP-240 & 16 & 0.245 & 0.01 & $2.3 \mathrm{E}-01$ & & 3074.3 & 3533.981 & & $3,7 E+04$ & $2.0 E+04$ & $<2.8 E+03$ & $<3.0 \mathrm{E}+03$ & $4.4 \mathrm{E}+06$ & $3.7 E+04$ & & & $\leq 1.5 \mathrm{E}+04$ \\
\hline CP-241 & 16 & & 0.02 & $6.2 \mathrm{E}-02$ & & 2536.1 & & & $3.8 \mathrm{E}+04$ & $6.5 \mathrm{E}+03$ & $\leq 9.5 \mathrm{E}+02$ & $<9.0 \mathrm{E}+02$ & $4.1 E+06$ & $7.9 \mathrm{E}+03$ & & & $1.2 E+04$ \\
\hline CP-248 & 1 & & 0.02 & $2.8 \mathrm{E}-04$ & & 17.03 & 11.262 & & & & & & & & & & \\
\hline CP-247 & 3 & & & $2.3 \mathrm{E}-04$ & & 52.22 & 8.495 & & & & & & & & & & \\
\hline $\mathrm{CP}-246$ & 5 & & & $8.2 E-04$ & & 108.57 & 5.777 & & & & & & & & & & \\
\hline$C P-245$ & 9 & & -5 & $1.3 \mathrm{E}-03$ & & 250.23 & & & & & & & & & & & \\
\hline CP-244 & 12 & & & $5.9 \mathrm{E} \cdot 03$ & & 541.78 & & & & & & & & & & & \\
\hline CP-243 & 14 & & & & & & & & & & & & & & & & \\
\hline CP-242 & 16 & & 0.02 & $3.7 E-02$ & & 2772.9 & & & $1.5 E+04$ & $4.8 \mathrm{E}+03$ & $<7.8 E+02$ & $<7.5 E+02$ & $3.8 \mathrm{E}+06$ & $3.4 E+03$ & & & 1.1E+04 \\
\hline C-Bank aro & & & & & & & & & & & & & & & & & \\
\hline $\begin{array}{l}\text { C-Bank, orga } \\
\mathrm{CW}-313\end{array}$ & & 2.1 & & $3.0 E-04$ & & $85 . \overline{84}$ & & & $=+04$ & $<6.3 \mathrm{E}+03$ & $<2,1 E+03$ & 03 & $1.5 E+06$ & & & & $=1.1 E+04$ \\
\hline CW-314 & $\frac{1}{1}$ & & & $\begin{array}{l}3.0 E-04 \\
4.4 E-03 \\
\end{array}$ & & & & & $<4.6 \mathrm{E}+03$ & $<1.4 \mathrm{E}+03$ & $<5.0 \mathrm{E}+02$ & $<5.2 \mathrm{E}+02$ & $\frac{1.0 \mathrm{E}+00}{1.8 \mathrm{E}+06}$ & $<9.6 \mathrm{E}+02$ & & & $\begin{array}{r}1.1 \mathrm{E}+4 \\
2.1 \mathrm{E}+03 \\
\end{array}$ \\
\hline$C W-315$ & 1 & & & & & 85.93 & & 5.045 & $<1.4 E+04$ & $<4.0 E+03$ & $<1.9 E+03$ & $<6.8 E+02$ & $1.3 \mathrm{E}+06$ & $<4.0 E+03$ & & & $<8.1 E+03$ \\
\hline CW-316 & 3 & & & $2.9 E-04$ & 1.254 & 90.74 & & 1.738 & & & & & & & & & \\
\hline CW-317 & 5 & & & 1.1E-04 & 0.132 & 81 & & 0.750 & & & & & & & & & \\
\hline CW-318 & 9 & & & $3.3 E-05$ & 0.025 & 98.64 & & 0.394 & & & & & & & & & \\
\hline CW-319 & 12 & & & 2.7E-03 & 0.464 & 167.71 & & 0.310 & & & & & & & & & \\
\hline CW-320 & 14 & & & $4.3 \mathrm{E}-02$ & & & & & & & & & & & & & \\
\hline$C W-321$ & 18 & & & $2.1 E-02$ & 0.560 & 396.64 & & 0.143 & & & & & & & & & \\
\hline & & & & & & & & & & & & & & & & & \\
\hline
\end{tabular}


ORNL/TM-12784

\section{INTERNAL DISTRIBUTION}

1-5. D. E. Benker

6. W. D. Bond

7. L. W. Boyd

8. F. R. Chattin

9. E. D. Collins

10 J. L. Collins

11. B. Z. Egan

12-16. L. K. Felker

17. J. B. Knauer

18. A. P. Malinauskas

19. C. P. McGinnis

20. L. E. McNeese
21. B. A. Moyer

22. M. K. Savage

23. B. B. Spencer

24. J. S. Watson

25. R. M. Wham

26. Central Research Library

27-28. ORNL Laboratory Records

29. ORNL Laboratory Records, RC

30. ORNL Patent Section

31. Y-12 Technical Library

Document Reference Center

\section{EXTERNAL DISTRIBUTION}

32. T. A. Fryberger, U.S. Department of Energy, 19901 Germantown Road, Germantown, MD 20585

33. S. M. Gibson, U.S. Department of Energy, Trevion II Building, 12800 Middlebrook Road, Germantown, MD 20874

34. R. L. Gilchrist, Westinghouse Handford Company, P.O. Box 1970, L5-63, Richland, WA 99352

35. R. D. Korynta, U.S. Department of Energy, Oak Ridge Operations, P.O. Box 2001, Oak Ridge, TN 37831-8620

36. W. L. Kuhn, Pacific Northwest Laboratory, Battelle Boulevard, P.O. Box 999, K2-21, Richland, WA 99952

37. G. J. Lumetta, Pacific Northwest Laboratory, Battelle Boulevard, P.O. Box 999, P7-25, Richland, WA 99352

38. J. O. Moore, U.S. Department of Energy, Oak Ridge Operations, P.O. Box 2001, Oak Ridge, TN 37831-8620

39. M. J. Quadrel, Pacific Northwest Laboratory, P.O. Box 1970, L5-63, Richland, WA 99352

40. J. L. Straalsund, Pacific Northwest Laboratory, Battelle Boulevard, P.O. Box 999, Richland, WA 99352

41. J. L. Swanson, Pacific Northwest Laboratory, Battelle Boulevard, P.O. Box 999, P7-25, Richland, WA 99352

42. P. S. Szerszen, SAIC, Quince Orchard Road, Suite 500, Gaithersburg, MD 20878

43. G. F. Vandegrift, Argonne National Laboratory, Chemical Technology Division, Argonne, IL 90439

44. Office of Assistant Manager, Energy Research and Development, DOE-ORO, P.O. Box 2008, Oak Ridge, TN 37831-6269

45-46. Office of Scientific and Technical Information, P.O. Box 62, Oak Ridge, TN 37831 